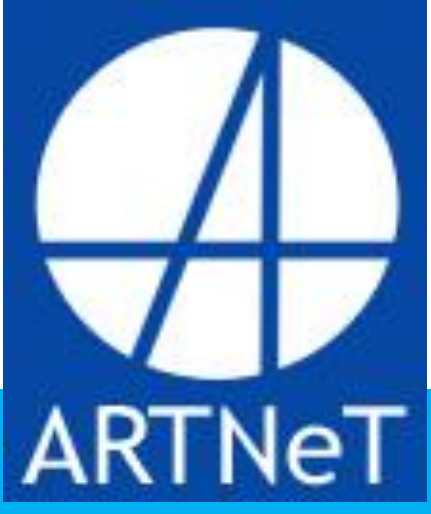

Trade facilitation and poverty reduction in Asia and the Pacific: A case study of a South Asian Economic Corridor
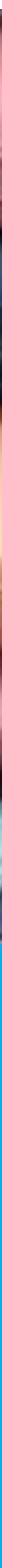

Prabir De and Ajitava Raychaudhuri

ASIA-PACIFIC RESEARCH AND TRAINING NETWORK ON TRADE Working Paper NO. 131 | SEPTEMBER 2013 
The Asia-Pacific Research and Training Network on Trade (ARTNeT) is an open regional network of research and academic institutions specializing in international trade policy and facilitation issues. IDRC, UNCTAD, UNDP, ESCAP and WTO, as core network partners, provide substantive and/or financial support to the network. The Trade and Investment Division of ESCAP, the regional branch of the United Nations for Asia and the Pacific, provides the Secretariat of the network and a direct regional link to trade policymakers and other international organizations.

The ARTNeT Working Paper Series disseminates the findings of work in progress to encourage the exchange of ideas about trade issues. An objective of the series is to publish the findings quickly, even if the presentations are less than fully polished. ARTNeT Working Papers are available online at www.artnetontrade.org. All material in the Working Papers may be freely quoted or reprinted, but acknowledgment is requested, together with a copy of the publication containing the quotation or reprint. The use of the working papers for any commercial purpose, including resale, is prohibited.

\section{Disclaimer:}

The designations employed and the presentation of the material in this Working Paper do not imply the expression of any opinion whatsoever on the part of the Secretariat of the United Nations concerning the legal status of any country, territory, city or area, or of its authorities, or concerning the delimitation of its frontiers or boundaries. Where the designation "country or area" appears, it covers countries, territories, cities or areas. Bibliographical and other references have, wherever possible, been verified. The United Nations bears no responsibility for the availability or functioning of URLs. The views expressed in this publication are those of the author(s) and do not necessarily reflect the views of the United Nations. The opinions, figures and estimates set forth in this publication are the responsibility of the author(s), and should not necessarily be considered as reflecting the views or carrying the endorsement of the United Nations. Any errors are the responsibility of the author(s). Mention of firm names and commercial products does not imply the endorsement of the United Nations. 


\title{
Trade facilitation and poverty reduction in Asia and the Pacific: A case study of a South Asian Economic Corridor
}

\author{
Prabir De* and Ajitava Raychaudhuri ${ }^{\dagger}$
}

Please cite this paper as: De, Prabir and Ajitava Raychaudhuri (2013). Trade facilitation and poverty reduction in Asia and the Pacific: A case study of a South Asian economic corridor

ARTNeT Working Paper Series No. 131, September, 2013, Bangkok, ESCAP.

\section{Available at www.artnetontrade.org}

\footnotetext{
*An earlier version of the paper was presented at the ARTNeT Conference on 'Empirical and Policy Issues of Integration in Asia and the Pacific', held at Colombo on 1-2 November 2012, and also at the ESCAP Seminar on 'Pro-poor Trade Facilitation and Measures in Developing Asian Countries', held at Bangkok on 26 March 2013. Authors would like to thank one anonymous referee, conference participants, Amrit Lagun, Rajan Ratna, Mia Mikic, and Yann Duval for their valuable comments on an earlier version of the paper. Authors are thankful to Sandip Singha Roy for field level data collection and Sreya Pan for research assistance. Support of ARTNeT/ESCAP is gratefully acknowledged. Views expressed by the authors are their personal. Usual disclaimers apply.

Senior Fellow, Research and Information System for Developing Countries (RIS), India Habitat Centre, Zone 4B, Fourth Floor, Lodhi Road, New Delhi 110 003, India; e-mail: prabirde@hotmail.com; prabirde@ris.org.in

† Professor and Coordinator, Centre for Advanced Studies, Department of Economics, Jadavpur University, Kolkata 700032, India; e-mail: ajitava1@gmail.com.
} 


\begin{abstract}
Relation between trade, inequality and poverty within countries is not beyond controversy. Under free trade and competitive conditions, trade promotes growth, and growth reduces poverty. In general, trade liberalisation has long been seen as an important element of an effective and sound economic policy and trade facilitation is a necessary step for achieving it. Trade facilitation is aimed at ensuring the movement and clearance of goods across borders within the shortest time at the minimum cost. Reducing trade costs can have a profound impact on trade and therefore on poverty. Based on primary survey data, this study assesses the potential impact of trade facilitation on poverty reduction in the region falling under SAARC Corridor 1, which is one of the leading corridors in South Asia that handles considerably good amount of overland trade between three major South Asian countries, namely, Bangladesh, India and Pakistan and also their global trade. One of the conclusions of this study is that poverty reduction, in the perception of the individuals connected with trade, depends on reduction in trade barriers through better trade facilitation. However, in the perception of the trading firms, better infrastructure which facilitates more trade is tagged with a positive response about decline of poverty.
\end{abstract}

Keywords: South Asia, Trade, Trade facilitation, Poverty, Economic Corridor

JEL codes: F14, F15 


\section{Contents}

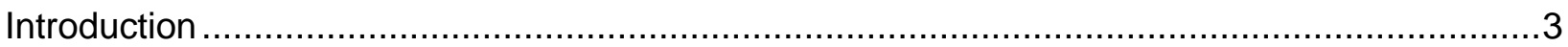

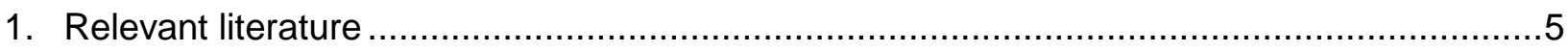

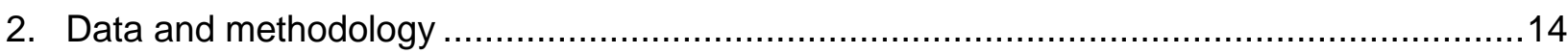

3. India's trade with Bangladesh and Pakistan ........................................................... 16

4. Trade facilitation and poverty: Major empirical findings ............................................19

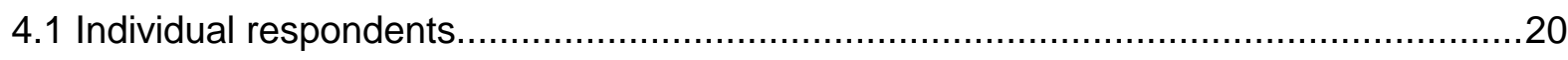

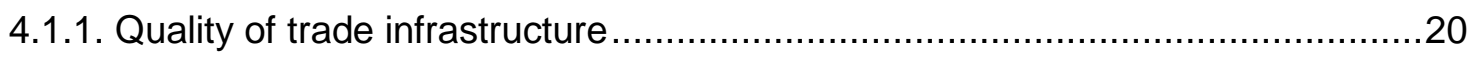

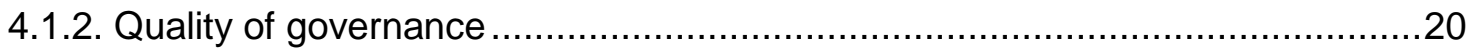

4.1.3 Individual perceptions about trade barriers ..............................................22

4.1.4 Opinions about trade, trade facilitation and poverty reduction ........................25

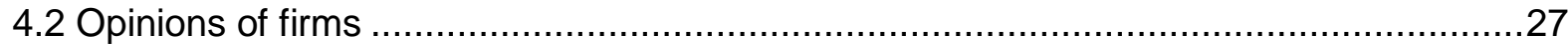

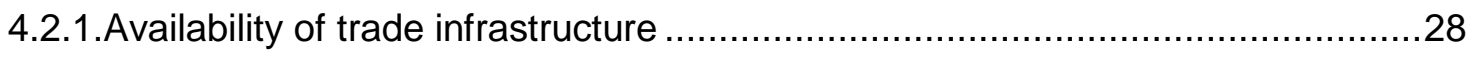

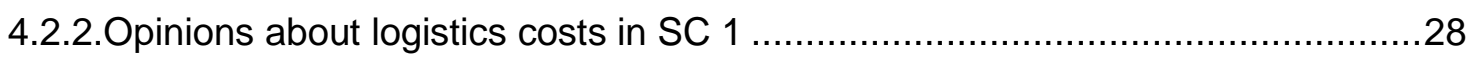

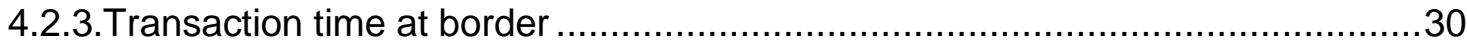

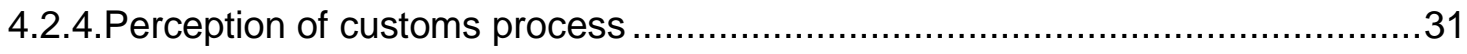

4.2.5. Trade barriers identified by Indian exporters and importers ............................32

4.2.6. Opinions of firms about trade facilitation and poverty ....................................34

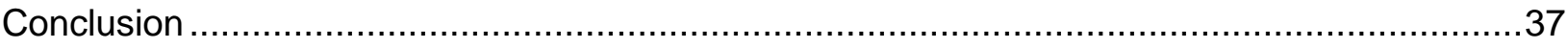

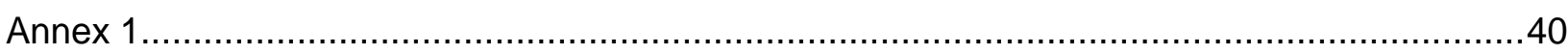

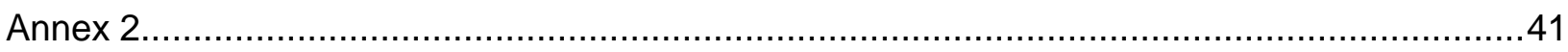

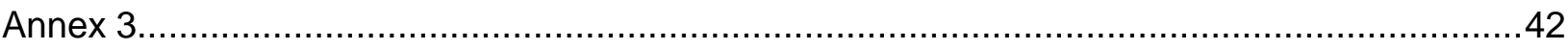

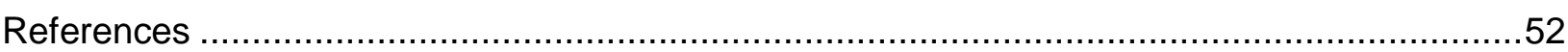




\section{List of Figures}

Figure 1: Sample size and distribution

Figure 2: Skill composition of individual respondents

Figure 3: Opinion of respondents about quality of trade infrastructure

Figure 4: Opinion of individual respondents on governance

Figure 5: Opinion of respondents on role of trade in poverty reduction

Figure 6: Distribution of firms in terms of trading partners

Figure 7: Skills composition in employment

Figure 8: Opinions on operational

Figure 9: Perception about poverty and trade facilitation

\section{List of Tables}

Table 1: India's trade with Pakistan

Table 2: India-Pakistan trade through the Attari-Wagah border

Table 3: Bangladesh trade with India

Table 4: India's exports through major ports

Table 5: Poverty rate, Tendulkar Methodology

Table 6: Marginal effects in elasticity of Ordered Probit Regression

Table 7: Logit regression results (individuals): Trade facilitation to reduce poverty

Table 8: Physical and non-physical trade barriers at Indian borders with Bangladesh and Pakistan
(a). Availability of facilities
(b). Non-availability of facilities

Table 9: Border transaction times
(a). Indian exports to Pakistan
(b). Indian exports to Bangladesh

Table 10: Perception about customs processing at border crossings

Table 11: Trade barriers faced by
(a). Indian exporters and importers with Pakistan
(b). Indian exporters and importers with Bangladesh

Table 12: Logit regression results (firms): Reduction of poverty by trade facilitation 


\section{Introduction}

The relationship between trade, inequality and poverty within any country is not immune to controversy. Under free trade and competitive conditions, trade promotes growth; that growth, in turn, reduces poverty. Reducing trade costs can have a profound impact on poverty (Winters and others, 2004). In general, trade liberalization has long been seen as an important element of an effective and sound economic policy, and trade facilitation is a necessary step towards achieving that objective (Winters, 2002). Trade facilitation is aimed at ensuring the movement and clearance of goods across borders within the shortest possible time at the minimum cost.

During the past two decades, import tariffs have decreased significantly and non-tariff measures aimed at further reducing international transaction costs have gained more importance in promoting trade across countries. Removal of non-tariff measures has been shown as a significant element in easing a country's economic isolation (Arvis and others, 2012). Efficient transportation networks have become a more important factor in regional cooperation, both in absolute and relative terms. Better trade and transportation infrastructure (termed as economic corridors) would encourage fragmentation of production across borders, enhance regional and global trade, and help in realizing the economic integration process. $^{1}$

Economic corridors became popular due to the Asian Development Bank (ADB) project in the Greater Mekong Subregion (GMS). ${ }^{2}$ An economic corridor can be national (e.g., the Delhi-Mumbai Industrial Corridor), regional (e.g., GMS corridors) or even international (e.g., submarine telecommunication cables). In South Asia, the South Asian Association for Regional Cooperation (SAARC) Regional Multimodal Transport Study (SRMTS) has identified 10 highway corridors for the region; the SAARC Corridor 1 (hereinafter referred to as SC 1) was selected for this study to assess the empirical relationship between trade facilitation and poverty reduction. ${ }^{3}$

\footnotetext{
1 See, for example, Brooks and Stone (2010).

2 The economic corridor concept is one in which regions, covering two or more countries, are identified where infrastructure is specially promoted to strengthen trade and economic integration. The basic idea behind this concept is not just the promotion of trade across borders, but also economic development along such trade routes (Wiemer, 2009). The main advantage of promoting economic corridors is realized when trade across such corridors is sufficiently liberalized and seamless, thus lowering the cost of cross-border trading.

${ }^{3}$ It was necessary to select a SAARC Highway Corridor (SAARC Corridor) for this study as the region, unlike GMS, does not yet have an economic corridor in operation. Annex 1 contains a map of SC 1, which originates in the State of Tripura, located in north-eastern India, passes through Bangladesh, re-enters India from the east and then moves north into Pakistan through India's western border.
} 
Distinct economic corridors can have the following specific benefits: ${ }^{4}$

(a) Improvement of national and regional connectivity by making it faster, cheaper, and easier for people and goods to move within and across borders;

(b) Aiding the reduction of poverty by improving poor people's access to economic opportunities, lowering the cost of the goods and services that they consume, and providing better access to essential infrastructure services such as electricity supply.

For most developing economies, economic corridors are viewed as stocks of public capital, thereby constituting a major constraint to growth. Shortages of economic corridors (i.e., infrastructure) cause congestion and, as a result, a strong tendency towards diminishing returns on capital in industry. A consequent low rate of return acts as a disincentive to investment and trade facilitation.

The issue of poverty reduction is always an important one, and trade facilitation may help in the process since it enhances competitiveness of a country or a region. ${ }^{5}$ The objective of the current study is to identify some causal factors that relate trade facilitation to poverty reduction. It is important to assess the trade facilitation and poverty linkage, since it can help countries to undertake policy reforms in order to facilitate trade (e.g., by making improvements in trade logistics).

In particular, this study attempts to assess the potential impact of trade facilitation on poverty reduction in SC 1. The focus of the study is on the Indian side of the corridor since India has undertaken trade facilitation measures relatively more intensively than its neighbouring countries who are connected by this corridor. ${ }^{6}$

Rest part of this study is structured as follows. Section 2 carries a literature review on economic corridor, trade facilitation and poverty, and identifies the research gaps. Data and methodology are briefed in section 3. Section 4 presents India's trade with Bangladesh and Pakistan, more through land borders. The primary survey results and analysis are presented in section 5 , followed by the conclusion in section 6 .

\footnotetext{
${ }^{4}$ See to Srivastava and Kumar (2012), in which a detailed account is provided of the economic benefits of GMS economic corridors.

5 See, for example, Bandara and others (2011).

${ }^{6}$ The idea being that where India has undertaken many more unilateral trade facilitation measures than its partners of the corridor, then those partners may enjoy the same gains if they accelerate their trade facilitation measures and vice versa. For example, India's Integrated Check Post (ICP) project has motivated its neighbours to develop their border infrastructure.
} 


\section{Relevant literature}

The awareness of trade facilitation is as old as trade itself. Many of the international trade agreements are designed to achieve this objective. Trade Facilitation as an independent concept gained attention with the Doha Round of WTO negotiations. Trade facilitation is aimed at ensuring the movement and clearance of goods across borders within the shortest time at the minimum cost. ${ }^{7}$ The two elements which form the crux of the issue are time and cost. Trade facilitation would mean addressing these issues and attempting ways and means to minimize the cost and time taken for movement of import and export cargo.

The relation between trade, inequality and poverty has been dealt extensively in literature. Most international trade economists have a perspective of a world in which countries exchange goods, factors and ideas. Free trade in goods leads to equalization of factor prices across countries according to the factor-price-equalization theorem. In the traditional literature on neo-classical growth model, capital and labour play the central role as two main factors of production. From the perspective of conventional one sector neo-classical growth theory international linkages do not matter, but from the trade perspective they are the crucial determinants.

Harrison et al (2010) presented a review of a detailed account of trade and inequality literature, and indicated that trade can affect (and usually increase) income inequality mainly because of within-industry effects due to heterogeneous firms; effects of offshoring of tasks; effects of incomplete contracting; and effects of labour-market frictions.

Under free trade and competitive conditions, trade promotes growth, and growth reduces poverty. ${ }^{8}$ In the literature on international trade, the issues of income distribution, growth as well as distortions are more or less discussed in terms of endowments of capital and labour, their growth and their relative prices. Countries that initially had a more regulated trade sector experienced an increase in inequality where trade reform, however, does not appear to have significantly affected changes in income distribution. ${ }^{9}$ In the income distribution literature, the functional distribution of the two major factors of production again explains the movement of

\footnotetext{
7 The definition of trade facilitation in broader terms goes beyond what has been noted in the WTO. In literature, trade facilitation has been identified as the means to move trade across borders which is not just restricted to dealing country's customs formalities.

${ }^{8}$ The linkage between trade and growth has been dealt extensively in literature. For a thorough review of the studies dealt the relationship between trade and growth, refer Singh (2010).

9 There is strong literature on trade and income distribution supporting the fact that trade liberalisation does not necessarily lead to equality of income in the presence of trade distortion. See, for example, Edwards (1997), Slaughter (1997).
} 
inequality in income distribution over time. ${ }^{10}$ Although infrastructure (or trade facilitation) plays the role of a very important catalyst, it gets virtually no explicit mention in the relevant literature on trade and inclusive growth. ${ }^{11}$ In fact, one may say that more trade openness or globalisation is potentially beneficial to all but requires appropriate policy designs to realize it. Trade facilitation may be seen in this perspective.

A group of literature indicates that trade facilitation potentially affects poverty through growth, trade and revenue channels (Figure 1). For example, trade facilitation influences international trade flows which modify the prices of goods and factors of production (capital and labour); government revenue which can be used for pro-poor and social expenditures; and economic growth. These changes alter income distribution and poverty levels. ${ }^{12}$

Trade liberalisation has long been seen as an important element of an effective and sound economic policy and trade facilitation is a necessary step for achieving it. Trading more efficiently tends to increase average incomes, providing more resources with which to tackle poverty (Bandara et. al, 2011). And while it may affect income distribution, it may not do so in a systematically adverse way.

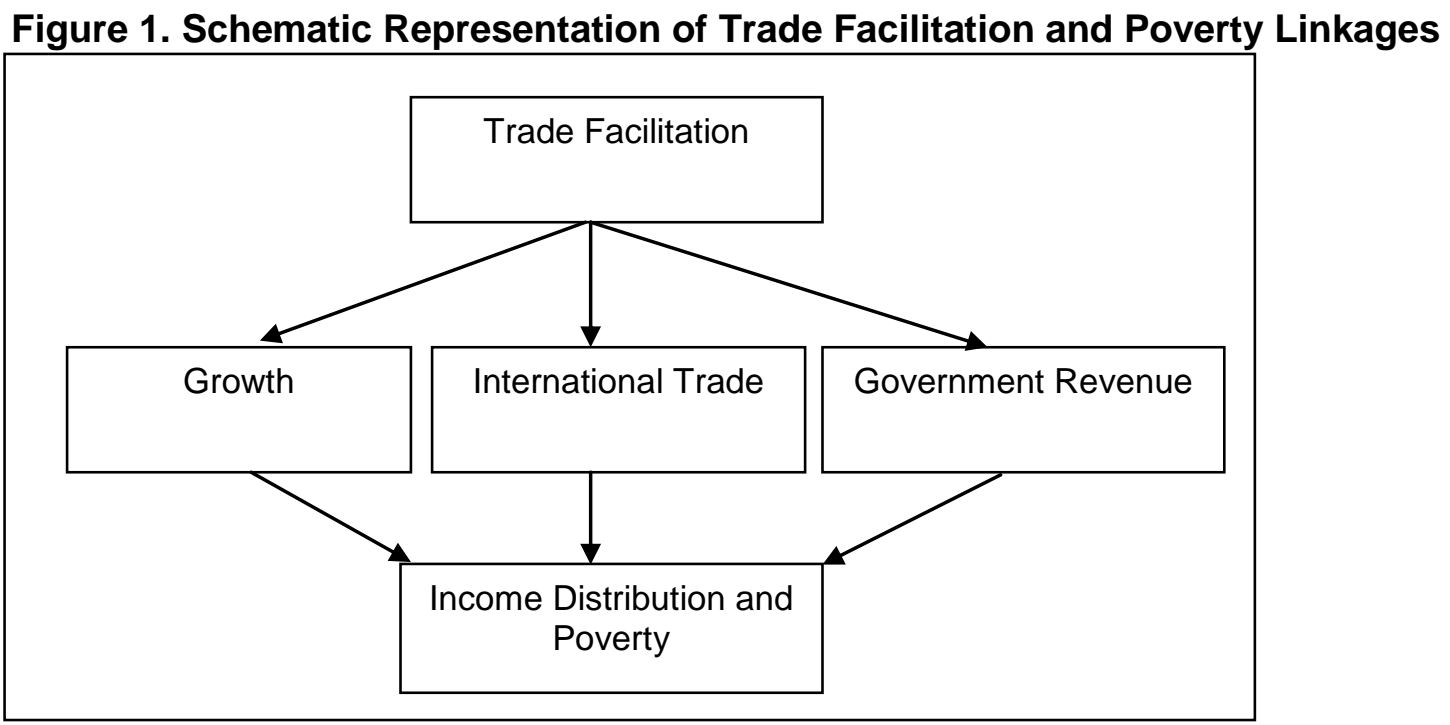

Source: UN (2003)

\footnotetext{
10 Refer, for example, Campano and Salvatore (2007), Gourdon et al. (2008).

11 However, development in endogenous growth theory has introduced the possibility of a productive role of public expenditure on infrastructure with an associated possibility of increasing returns to scale (Barro 1990, 1991).

${ }^{12}$ However, in theoretical terms trade facilitation has a positive impact on the efficiency of the trading environment which increases average incomes providing more resources to tackle poverty. However, as with most trade reforms, trade facilitation may adversely affect some groups in society even if it increases incomes in total.
} 


\section{Box 1. Trade Costs and Poverty in Rwanda}

Increasing incomes in rural areas is necessary for poverty reduction in Rwanda since the majority of the poor live in rural areas. Improvements in returns to exportable commercial crops are the most direct and probably the most effective way of increasing the flow of cash into rural areas and so must lie at the heart of poverty reduction in Rwanda. Diop et al (2005) found that reducing trade costs can have a profound impact on poverty. The benefits of lower transport costs, if reflected in higher producer prices, will be realized by all coffee farmers, and indeed all commercial farmers. Reducing transport costs and providing access to transport to those who are currently remote is therefore a crucial element in the poverty reduction strategy. Similarly, this study has shown that the government's strategy of increasing returns by raising quality and therefore the market price of Rwandan produce will have a significant impact on poverty, particular if small farmers are targeted and assisted in improving the quality of their coffee crop. However, the success of this strategy requires effective rural logistics services and transport capacity, to ensure that coffee is washed in good time before its quality starts to deteriorate. This capacity is currently lacking. This study has found significant impacts on poverty while only considering the most direct reactions to changing prices. However, the effects will be considerably larger, since coffee farmers typically have a high propensity to spend on other products produced in the rural communities. Increasing returns to commercial farmers could have substantial multiplier effects within rural communities. The challenge is to provide an infrastructure and framework by which rural markets can develop and flourish. Given the current level of development in Rwanda it is clear that this will require a significant response and engagement from the international institutions and donors.

Source: Diop et al (2005)

The neo-classical as well as new trade theories rely on a two-country, two-factor and two-goods model (the $2 \times 2 \times 2$ model). Thus, infrastructure (trade facilitation) appears as a complementary factor that facilitates trade. ${ }^{13}$ This will visible in following ways: (a) it has a strong positive influence on trade volume (Deardorff 2001), or (b), it might influence trade cost (Anderson and van Wincoop 2004). Appendix 2 provides a schematic view of the links between trade and poverty. Falling trade cost can have profound impact on poverty in developing countries (see Box 1). Analyzing the importance of different channels that link trade reforms and household welfare, Isik-Dikmelik (2006) in a case study on Vietnam commented that trade reforms has benefited everybody but especially the poor.

Economic corridor like infrastructure might influence trade cost more than tariff and non-tariff barriers, but measurement is probably more difficult. Infrastructure is a composite term, for example, measured as an average of the density of the road network, the paved road network, the rail network and the number of telephone main lines per person. The supposed impact of tariff and non-tariff barriers may be less in magnitude compared to inefficiency-related and enforcement-related costs of infrastructure. Although it is difficult to measure it accurately and directly, according to Limao and Venables (2001) trade costs

\footnotetext{
${ }^{13}$ In some literature, trade facilitation has been seen as a process to improve country's infrastructure. Refer, for example, Brooks and Stone (2010)
} 
depended heavily on infrastructure. A similar conclusion was reached in some recent studies, which showed that port infrastructure was the most important factor in the reduction of trade costs for Asian countries, given the preponderance of sea freight in trade costs for Asian countries (De 2009a; Brooks and Hummels 2009).

Although an OECD (2003) study on trade facilitation dealt mainly with the World Trade Organization (WTO) definition of border-related trade transaction costs, it made the following interesting observations. After analysing border process quality across 102 countries it found that those countries with a higher per capita income generally scored better with regard to border process quality than countries whose inhabitants were less well off. However, some countries those were not particularly well off exhibited better border processing. The study concluded that low-income countries did not necessarily have to wait until they became rich before being able to adopt good border practices. Meschi and Vivarelli (2009) analysed intra-country income differences taking 65 developing countries spanning over 1980-1999. Using a dynamic panel data analysis of Arellano and Bond variety, the authors found that trade really does not significantly influence income inequality within countries, although some other control variables like education (through skill-formation) and inflation rate do have significant impact.

While dealing with the relative importance of trade-mandated effects on industry wage premia; industry and economy-wide skill premia; and employment flows in accounting for changes in the wage distribution during the 1988-1995 trade liberalization, Ferreira et al (2009) commented that unlike in other Latin American countries, trade liberalization has appeared to have made a significant contribution towards a reduction in wage inequality in Brazil. Raychaudhuri and De (2012) analysed the impact of increased trade in services in India on inequality. They found that one major component of India's service sector growth comprised information and communication technology (ICT) services. The study showed that the ICT sector led the service trade in India. However, the sector is skill and infrastructure intensive. The major IT and IT-enabled services are located in big metropolitan cities. As a result, the sector does not support unskilled workers nor has it made its presence felt in the rural areas. Thus, this type of increase in services trade has increased the inequality within the urban regions of India as well as greater income divergence between rural and urban incomes.

Reducing trade costs and facilitating transit is two of the key approaches to achieving a more inclusive growth through trade, i.e., one that will reduce the gap between the economic core and the outer periphery of each of the South Asian economies (De, 2009b). Doing so will 
encourage economic activity at and across borders, eventually generating employment through industrialization as well as benefiting the poor of the border areas and landlocked countries. However, governments will also need to provide adequate education and capacity-building opportunities for the people living in such areas so that they can effectively engage in trade.

\section{Box 2. Income Distribution Impact of Trade Facilitation in Developing Countries}

- Trade facilitation has an impact on income distribution and poverty in developing countries through its effects on international trade, economic growth and government revenue.

- Small and medium sized enterprises (SMEs), the dominant actors in developing countries, are the main beneficiaries of trade facilitation, since trade transactions costs fall disproportionately on small firms.

- While trade facilitation may or may not reduce income inequalities within developing countries, trade facilitation can enhance trade-induced growth, which increases average incomes providing more resources with which to tackle poverty.

- Trade facilitation measures applied within a closed (or at least less liberal) trade environment can still have a positive impact on exports and foreign investment.

- Trade facilitation may increase employment which may help some move out of poverty.

- Improvements in infrastructure allow the poor to trade more easily and profitably in domestic as well as in international markets.

- Trade facilitation can increase government revenue which can benefit the poor if used to finance social expenditures

Source: UN (2003)

\section{Trade Facilitation and Poverty}

Improved trade facilitation makes the trade efficient which tends to increase average incomes, providing more resources to tackle poverty. And while it may affect income distribution, it may not do so in a systematically adverse way (UN, 2003). ${ }^{14}$ Box 2 captures some stylized facts on income distribution impact of trade facilitation in developing countries. Noted in UN (2003), ${ }^{15}$ there are three main ways that trade facilitation initiatives can affect the distribution of income, and hence aid poverty reduction in a society (Figures 1 and 2).

One, trade facilitation increases the volume and range of a country's international trade, by reducing the transaction costs of trade, making exports more competitive, leading to increase in wages and the numbers employed in the exporting sectors, and imports less expensive, thereby also increasing real wages. One example of the direct effect of how an improvement

\footnotetext{
${ }^{14}$ For example, in context of 14 Asia-Pacific countries, Raychaudhuri and De (2010) found strong influence of trade openness and infrastructure on income inequality but not the reverse one. Country-specific factors turned out to be important determinants of trade openness and income inequality. Further, this study also argued initial values of both income inequality and trade openness as important determinants in the evolution of these variables, apart from the positive influence of infrastructure as a determining variable.

${ }_{15}$ Based on Overseas Development Institute (2003)
} 
in the supply chain can help Lao PDR or Nepal to higher market access in ASEAN and SAARC, respectively.

Two, trade facilitation can then contribute to economic growth, which in turn will lead to higher incomes, greater employment and a positive effect on poverty. The process also generates a number of by-products; firstly, as the economy becomes stronger, with a broader trading base, it becomes less vulnerable to exogenous shocks. Secondly, an improved milieu for trade changes the incentives to invest, leading to greater foreign direct investment and increases in investment in human capital.

Three, the final way that trade facilitation can impact on income distribution and poverty relates to the increase in government revenues, that is the concomitant of increased trade, improved efficiency and reduced corruption, allowing greater expenditures on social programmes.

Figure 2. Trade Facilitation Helps in the Reduction in Poverty

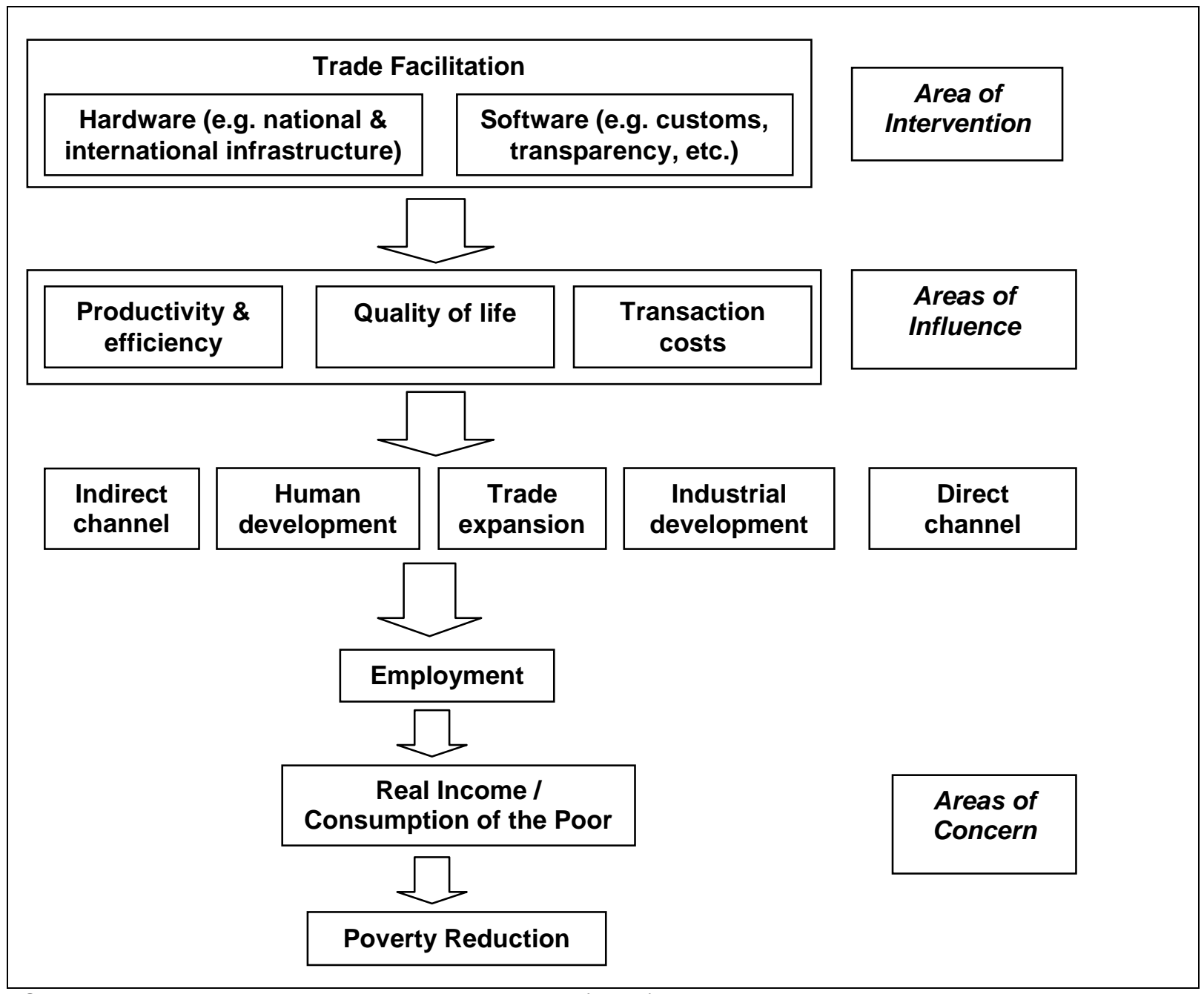

Source: Authors based on Raychaudhuri and De (2010) 


\section{Trade, Poverty and Labour Market}

The link between international trade (and also trade facilitation) and poverty in developing countries is normally via the labour market (Winters 2000). If opening up to international trade allows a country to export more labour-intensive goods and replace local production of capital and skill-intensive goods by imports, it increases the demand for labour - typically in the formal sector. If poverty is concentrated among people who are actually or potentially part of the labour market, increasing demand will help to alleviate poverty. But how, and whether, it does so depends significantly on how the labour market operates.

Figure 3. Demand for Labour

(a)

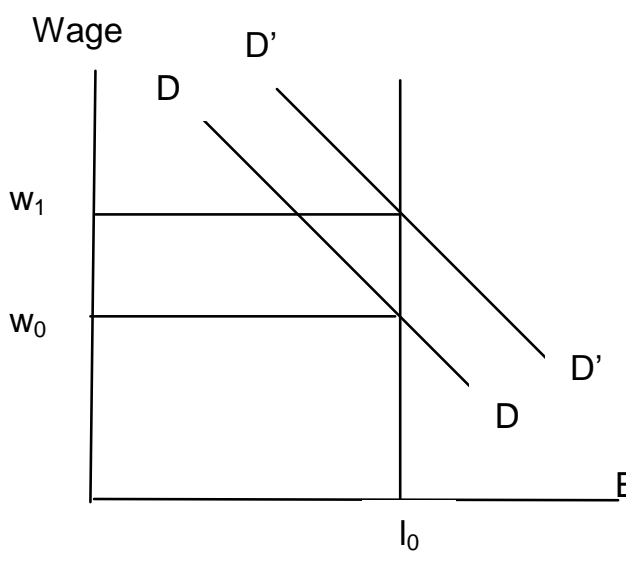

(b)

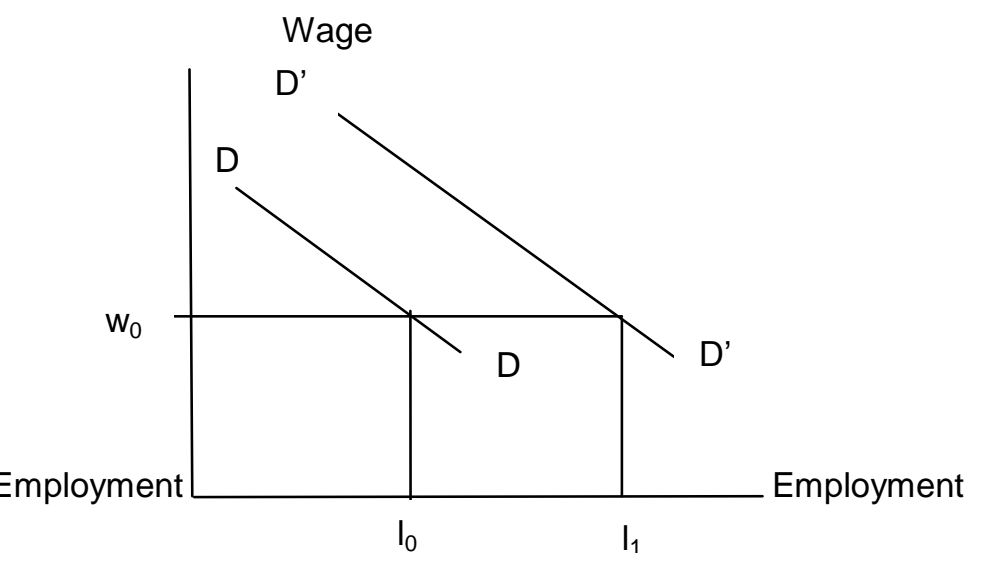

Source: Adapted from Winters (2000)

Consider following two assumptions. ${ }^{16}$ In Figure 3(a) we assume that the supply of labour to the formal sector is completely fixed. When the demand for labour shifts out from DD to D'D', employment cannot increase and the market must be brought back to equilibrium by an increase in wages from $w_{0}$ to $w_{1}$. If some of the workers in this market were poor - or were part of poor families - the increase in wages has a direct and beneficial impact on poverty. This is the classic "Stolper-Samuelson" result that appeared to work so strongly in East Asia over the 1970 s and 1980s.

In the Figure 3(b), the supply of labour is perfectly elastic at the prevailing wage. Now an increase in labour demand is accommodated by increasing employment to $l_{1}$, with no change in wages. The effect on poverty depends heavily on what the additional workers were doing before accepting these new jobs. If they were engaged in subsistence activities - agriculture, scavenging - and earning the equivalent of $w_{0}$ initially, there is no change in their situation.

${ }^{16}$ Adapted from Winters (2000) 
Only if the switch into this labour market was so great as to significantly reduce labour supply to the subsistence sector and hence raise its "wage" there would be a poverty impact. In this case, the increase would apply to all workers in formal and subsistence sectors and so potentially would have very widespread benefits. However, the increase in labour demand would have to be huge to have a material effect on the wage. This case is really no less than the case of successful development, through which whole economies are transformed over a period of decades. Trade liberalisation is probably an important part of the process, but it is not the only one.

Figure 4. Trade Facilitation and Economic Outcomes

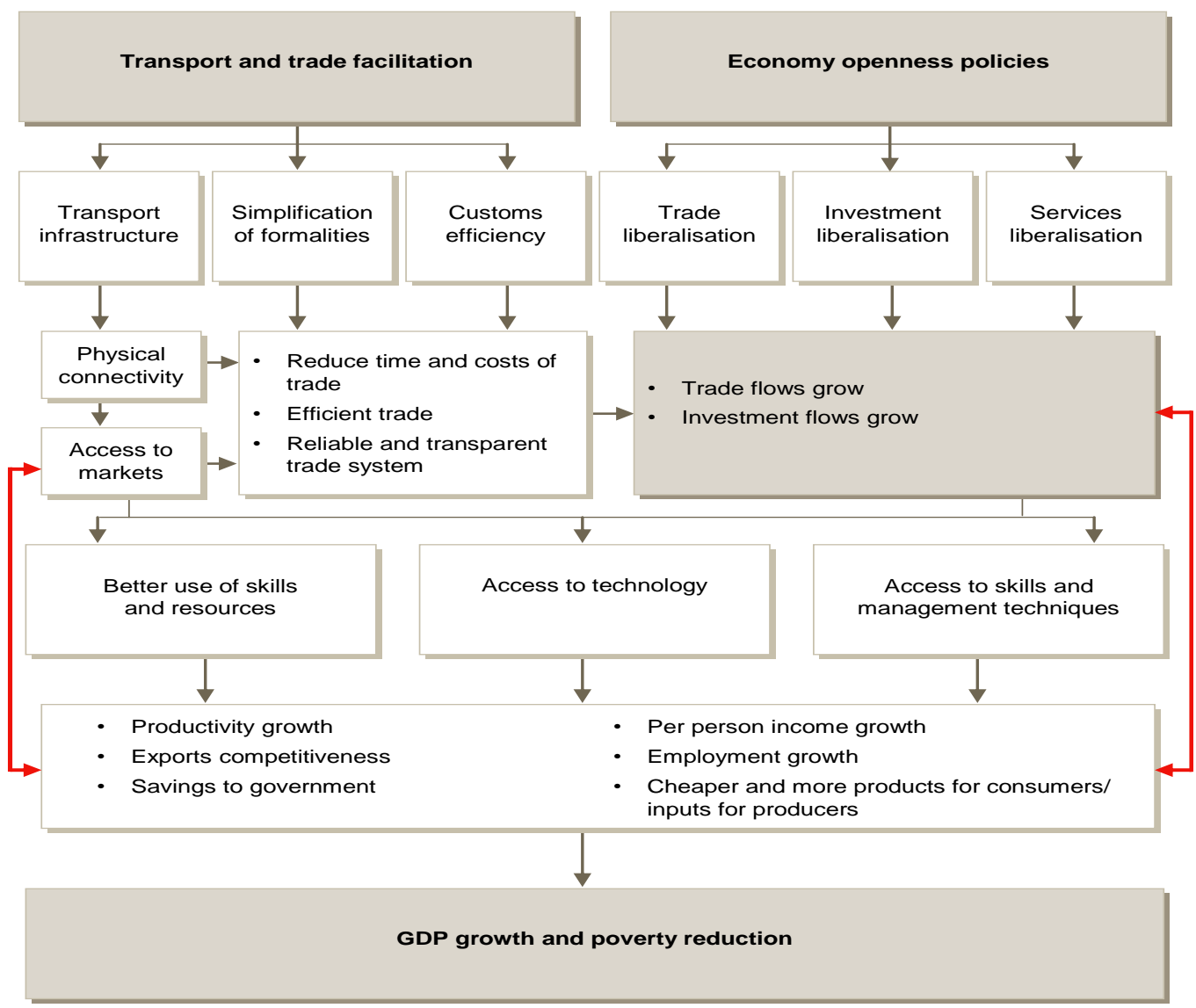

Source: CIE (2012)

\section{Trade Facilitation and Economic Outcomes}

Open policies and trade facilitation help in achieving economic outcomes, through which poverty reduction (CIE, 2012). The most visible case is the development of economic corridors in GMS subregion, where improvements in trade and transport facilitation have 
assisted the GMS region in further reducing poverty and improving living standards. ${ }^{17}$ Figure 4 illustrates the way in which trade facilitation policies complement open trade and investment policies in enabling growth and poverty reduction.

Actions on the trade facilitation agenda may include improving physical connectivity through transport infrastructure projects; easing the transit of vehicles, goods and people between borders; simplifying processes and procedures to trade; making customs systems more efficient and transparent through automation and sharing of information between crossing points; among others. In a broad sense, these actions reduce transaction costs of trade, making trade more efficient and reliable and stimulating its growth. ${ }^{18}$

\section{Application of CGE and Gravity Models}

There have been several studies attempting to estimate the benefits of trade facilitation. The impact of trade facilitation activities is seen in view of reduced time and costs of trading across borders stimulating trade and socio-economic outcomes.

There are two broad approaches for conducting the modelling. One is the use of gravity models. These models predict bilateral trade flows according to the sizes of the economies and the distance between the two countries analysed. Additional variables are included to analyse the impact of policies in the international trade sphere such as preferential trade agreements. These models have been useful for testing the relation between trade costs and increases in the volume of trade. ${ }^{19} \mathrm{~A}$ second approach is the use of computable general equilibrium (CGE) models which are more suited for explaining economy-wide effects of policies. The use of the Global Trade Analysis Project (GTAP) model is common for capturing such effects. This model incorporates relations between economic sectors and countries, resource constrains and an economic framework that accounts for the behaviour of consumers and firms. ${ }^{20}$

\footnotetext{
17 Refer, for example, Warr et al (2009), Menon (2006), etc.

18 Refer, for example, Raychaudhuri and De (2013)

${ }^{19}$ For example, Edmonds and Fujimura (2008) (gravity model and panel data) show lower transport cost along GMS corridors benefits trade directly and reduces poverty.

${ }^{20}$ For example, Menon and Warr (2006) (CGE model) analyzed relationship between road improvement and poverty reduction in Lao PDR, and found strong correlation with reduced poverty incidence but important differences depending on type of roads and initial access conditions. This study shows importance of improving rural access to main GMS corridors to maximize inclusive impact. Besides, several ADB studies estimate transit costs reduction along EWC and the NSEC to range from 30-50 percent. In an another study (CGE model) on GMS, Stone et al (2010) found very significant improvement in welfare mainly originating in improved terms of trade and trade facilitation followed by allocative efficiency and transport.
} 
GTAP is a modelling framework that assists in quantifying the impacts of policy issues and has commonly being used for analysing impact of trade liberalization and trends. As with any other model it simplifies the real world to allow for analysis and prediction of the impact of policies on economic activity. It is a computable general equilibrium model that incorporates multiple economic sectors and regions, capturing the links between them by modelling the behaviour of and interaction between consumers, producers and government. The standard GTAP model is supported by the GTAP database which includes 57 sectors and over 100 countries. The database take account of bilateral trade patterns, production, consumption and intermediate use of commodities and services.

Finally, the foregoing discussion provides a synoptic view of the role of trade facilitation in growth and income distribution. The point that is emphasised throughout this paper is that trade facilitation basically appears as a complementary factor in the standard literature. The positive impact of trade facilitation on income and poverty reduction is proved through growth; however, the important point to note is that trade facilitation is a factor whose efficiency is as equally important as its quantity. Possibly this applies to all factors of production, but for trade facilitation this is emphasised time and again. The developing countries unambiguously show this positive impact, unlike some of the developed countries.

Unfortunately, most of the studies do not address either trade or income distribution issues due to complex relations more in an open economy framework. Causality is rather unknown. The literature that deals with inclusive growth and poverty highlights the fact that accessibility to infrastructure, like rural roads or electricity, does not benefit the poor much. Hence, the result may be an unintended widening of income disparity. Therefore, a group of literature suggests that the government has a stronger role to play in reducing poverty through improved trade facilitation programmes. The GMS case shows that improved regional connectivity is an important element in reducing poverty and making growth more inclusive through expansion of trade. The literature indicates that while transport improvements bring large benefits, improved trade facilitation has an even larger impact. This is where policy priorities are for developing countries.

\section{Data and methodology}

This study is based on both secondary and primary data. Econometric methods were used (e.g., ordered categorical regressions) to identify the existence of specific barriers to facilitation and to make a quantitative assessment of the impact of trade facilitation on poverty 
reduction. The analysis was based on field survey data, collected at selected places on the Indian side of SC 1. Firms and individuals were both covered through primary survey. The route of SC 1 (which is part of the Asian Highway 1) is via Lahore-New Delhi-Kolkata-Dhaka-Agartala. It connects three SAARC countries, i.e., Bangladesh, India, and Pakistan, and therefore carries a considerable amount of regional trade. Figure 5 shows the survey region and corresponding sample sizes. The field survey was conducted through a structured questionnaire (see annex 3 ) on a small scale (279 sample size) in the form of a pilot survey. The primary objective was to gain information quickly on the empirical relationship between trade facilitation and poverty reduction as well as to improve the efficiency of the main survey if conducted in future. ${ }^{21}$

\section{Figure 5. Sample size and distribution}

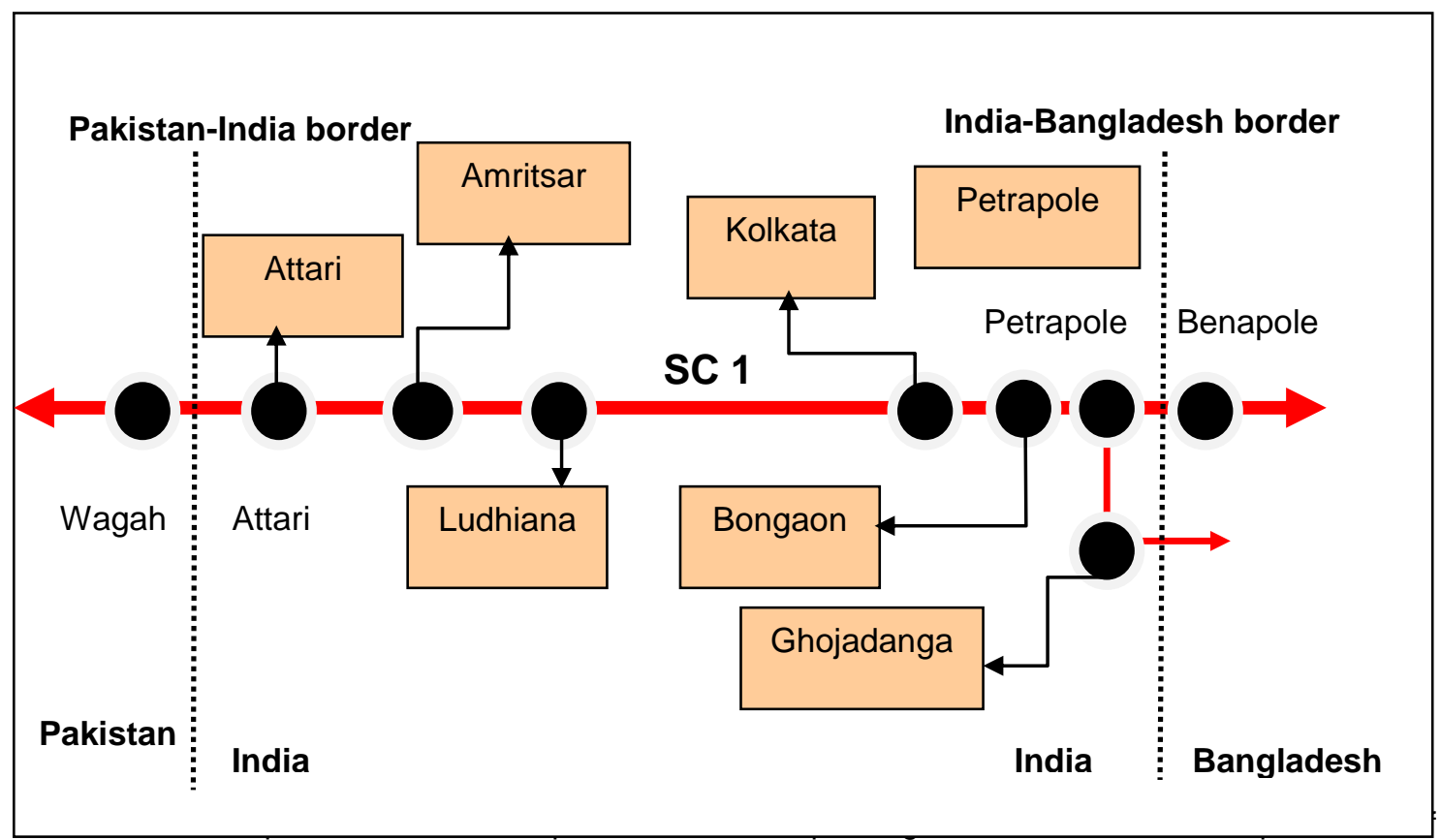

which samples of firms and individuals are 100 and 179, respectively.

Another objective for selecting SC 1 was that some of the industrial clusters connected by this corridor supply intermediate products to regional/bilateral production networks in the South Asia region. Exports of yarn from India's Ludhiana, India, to Dhaka, Bangladesh are a case in point. ${ }^{22}$ As a large number of people are involved when international trade is conducted along SC 1, their employment is directly linked with trade flows. The primary

\footnotetext{
21 The time and resources available for completing the project were sufficient for the pilot survey. This was exactly the purpose of this survey. A large-scale survey is possible now since the results from the pilot survey give a clearer vision of the role of trade facilitation in poverty reduction, based on perceptions of individuals and firms. However, a large-scale survey will need large-scale funding and sufficient time (for example, 24 months).

${ }^{22}$ Exports of yarn from India to Bangladesh alone contributed about 35 per cent of India's total exports to Bangladesh in 2010. In 2010, India exported over US\$ 1 billion textile goods including yarn to Bangladesh, where most of the yarn export originates at Ludhiana in Punjab state of India.
} 
survey therefore looked at whether or not improvement in trade facilitation along SC 1 has helped remove poverty.

Trade facilitation in SC 1 is therefore an important factor contributing not only to the expansion of trade but also production fragmentation within or across countries such as Bangladesh. With production processes and tasks becoming increasingly fragmented across national borders, trade facilitation measures such as time-sensitive logistics services together with information and communication technology are the key to assisting production networks across borders. The primary survey data identify the barriers to trading with Bangladesh and Pakistan along SC1.

\section{India's trade with Bangladesh and Pakistan}

Bilateral trade between India and Pakistan witnessed an upward trend only in the second half of the past decade, when it increased sharply owing much to the India-Pakistan "Composite Dialogue" in 2004. India's trade with Pakistan trebled in 2010 and reached an all-time record of US\$ 2.56 billion (table 1). India's exports to Pakistan increased much faster than imports from the latter country, thereby increasing India's trade surplus from less than US\$100 million at the beginning of the past decade to just over US\$1.94 billion in the first year of the ongoing decade (table 1). However, compared to their economic strength, trade between India and Pakistan is negligible and much below potential.

Table 1. India's trade with Pakistan

\begin{tabular}{lrrr}
\hline Year & Exports & Imports & Total trade \\
\cline { 2 - 4 } & \multicolumn{3}{c}{ (US\$ million) } \\
\hline 1990 & 43.49 & 44.86 & 88.35 \\
1995 & 70.40 & 37.37 & 107.77 \\
2000 & 163.33 & 65.05 & 228.38 \\
2005 & 647.19 & 158.42 & 805.61 \\
2010 & 2252.89 & 310.44 & 2563.33 \\
CAGR (\%) & & & \\
$1990-1999$ & 9.22 & 9.88 & 9.56 \\
$2000-2009$ & 27.45 & 17.32 & 25.18 \\
\hline Source: United Nations COMTRADE database.
\end{tabular}

The composition of Indian exports to Pakistan was primarily limited to about 14 commodities in 2010-2011, and which on average accounted for some 78 per cent of the total Indian exports to Pakistan. These commodities include sugar, raw cotton, synthetic fabrics, tea, petroleum products and chemicals, reflecting India's more diversified industrial base. Shares 
of both raw cotton and woven fabrics in India's exports to Pakistan increased from almost zero in 2000 to more than 13 per cent in 2010, whereas the share of oil-cake and other solid residues contracted from about 16 per cent to 3 per cent during the same period. The composition of official major imports from Pakistan to India has been limited to 18 commodities, such as fruit and vegetables, wool and wool products, petroleum products, chemicals, lead and, more recently, cement. These products together share about 88 per cent of India's total import from Pakistan. In 2010, the sectors with large shares in Pakistan's exports to India were fruit (19 per cent), followed by petroleum products (12 per cent), and cement (11 per cent) (De and others, 2013).

Trade between India and Pakistan has never expanded to the extent that it would have been in a normal trade environment due mainly to political disturbances. Until recently, the restrictive trade policies of both countries, with a variety of embedded trade barriers aimed at each other's market, did not allow bilateral trade to grow. Pakistan has 1,209 items on the negative list that are likely to be phased out, and there will be no restriction on tradeable items; this would encourage border trade between the two countries, particularly through Attari and Wagah, along SC 1. Trade valued at about Rs 41.79 billion was carried out in 2010-2011 through the Attari-Wagah border (table 2); this is likely to increase in view of Pakistan's proposal to India for most favoured nation (MFN) status and the dismantling of the positive list of trade at the India-Pakistan land border.

Table 2. India-Pakistan trade through the Attari-Wagah border

(Unit: Rs billion)

\begin{tabular}{lccc}
\hline Year & Exports & \multicolumn{1}{c}{ Imports } & Total \\
\hline $2007-2008$ & 17.40 & 34.67 & 52.07 \\
$2008-2009$ & 43.53 & 42.12 & 85.65 \\
$2009-2010$ & 79.81 & 39.59 & 119.40 \\
$2010-2011$ & 37.17 & 4.62 & 41.79 \\
\hline
\end{tabular}

Source: Sahai and Laxmi, 2013, based on Indian customs data.

Trade by Bangladesh with India has been growing steadily. India is Bangladesh's primary trading partner in South Asia, followed by Pakistan. Bangladesh has a high deficit in its trade with India - having increased from US\$ 44 million in 1981 to US\$2.5 billion in 2009. The 10-year period of 2000-2009 saw the fastest rise in Bangladesh's exports to India (20.49 per cent CAGR), while the growth of imports from India declined to 12.59 per cent per annum (table 3). Nevertheless, Bangladesh exports account for only 1 per cent of India's total imports and the range of products is small, comprising mostly fertilizers and jute products. Ready-made garments form Bangladesh's major exports, but the share going to India is very 
small, at least so far. A large part of India-Bangladesh trade passes through Petrapole (India) and Benapole (Bangladesh) along SC 1.

Table 4 gives some idea about the trade that passes through this border along SC 1. It clearly shows that land trade overwhelmingly outweighs sea trade, with the Petrapole border alone contributing about 57 per cent of India's exports to Bangladesh. Hence, the importance of SC 1 in regional trade cannot be ignored. This fact alone was an important reason for selecting this corridor for further investigation of the empirical relationship between trade facilitation and poverty.

Table 3. Bangladesh trade with India

\begin{tabular}{lrr} 
& (Unit: US\$ million) \\
\hline Year & Exports & Imports \\
\hline 1990 & 21.68 & 170.27 \\
2000 & 50.13 & 945.45 \\
2010 & 320.91 & 3859.82 \\
CAGR (1990s), (\%) & 9.61 & 22.06 \\
CAGR (2000s), (\%) & 20.49 & 12.59 \\
\hline Source: United
\end{tabular}

Source: United Nations COMTRADE database.

Table 4. India's exports through major ports

\begin{tabular}{lrrc} 
& \multicolumn{3}{c}{ (Unit: Per cent) } \\
\hline Land (road and rail) & $\mathbf{1 9 9 6 - 1 9 9 7}$ & $\mathbf{2 0 0 3 - 2 0 0 4}$ & $\mathbf{2 0 1 0 - 2 0 1 \mathbf { * } ^ { * }}$ \\
Petrapole (mainly road) & 56.6 & 36.2 & 57.2 \\
Ranaghat (Gede) (rail) & 5.2 & 11.5 & 17.5 \\
Radhikapur (rail) & 0.6 & 1.9 & 2.4 \\
Hili (Road) & 2.9 & 5.9 & 6.1 \\
Kotwaligate(Mohedipur by & 4.3 & 6.9 & 2.8 \\
road) & & & \\
Sea & & & \\
Mumbai & 9.3 & 1.3 & 0.6 \\
Nhava Seva & 3.3 & 5.3 & 7.1 \\
Chennai & 1.9 & 2.5 & 1.3 \\
Tuticorin & 1.8 & 1.5 & 0.7 \\
Vishakapatnam & 0.7 & 2.8 & 1.1 \\
Kakinada & 0.9 & 2.5 & 0.4 \\
Others & 12.5 & 21.7 & 2.8 \\
\hline
\end{tabular}

Source: Calculated based on DGCIS, Ministry of Commerce, Government of India

*Based on Indian Customs data. 
As shown in table 5, SC 1 passes through six Indian States (table 5), of which two - Bihar and Uttar Pradesh - have poverty rates that are higher than the national average. ${ }^{23}$ In addition, in absolute numbers, the percentage of poor people is relatively higher in those two States, compared to the other four States. Between 2004-2005 and 2009-2010 the rural poverty rate in Bihar only declined marginally from 55.7 per cent to 55.3 per cent, respectively. Therefore, trade facilitation in SC 1 is an important avenue for the lowering poverty rate.

Table 5. Poverty rate, Tendulkar Methodology

\begin{tabular}{lcccccc}
\hline State & \multicolumn{3}{c}{$\mathbf{2 0 0 4 - 2 0 0 5}$} & \multicolumn{3}{c}{ 2009-2010 } \\
\cline { 2 - 7 } & Rural & Urban & Total & Rural & Urban & Total \\
\hline Bihar & 55.7 & 43.7 & 54.4 & 55.3 & 39.4 & 53.5 \\
Delhi & 15.6 & 12.9 & 13.0 & 7.7 & 14.4 & 14.2 \\
Haryana & 24.8 & 22.4 & 24.1 & 18.6 & 23.0 & 20.1 \\
Punjab & 22.1 & 18.7 & 20.9 & 14.6 & 18.1 & 15.9 \\
Uttar & 42.7 & 34.1 & 40.9 & 39.4 & 31.7 & 37.7 \\
Pradesh & & & & & & \\
West Bengal & 38.2 & 24.4 & 34.2 & 28.8 & 22.0 & 26.7 \\
India & 42.0 & 25.5 & 37.2 & 33.8 & 20.9 & 29.8 \\
\hline Source: "Press & Note on Poverty Estimates, 2009-10", Planning Commission,
\end{tabular}
Government of India, 13 March 2012.

\section{Trade facilitation and poverty: Major empirical findings}

The primary survey was conducted among individuals residing near the borders at Attari (India-Pakistan), and Petrapole and Ghojadanga (India-Bangladesh), and who were dependent on trade with Bangladesh and Pakistan along SC 1. This section presents the major findings of the field survey for two separate categories - individuals and firms.

\footnotetext{
${ }^{23}$ The poverty rate developed by the Tendulkar Committee was followed here. The methodology uses implicit prices for estimating State-wise poverty lines for 2004-2005. Using these poverty lines and the distribution of monthly per capita consumption expenditure, based on a mixed reference period, the Tendulkar Committee estimated poverty ratios for 2004-2005. Implicit price indices (Fisher Price Index) have been computed from the 66th Round NSS (2009-2010) data on the Household Consumer Expenditure Survey. As per Tendulkar Committee recommendations, the State-wise urban poverty lines of 2004-2005 have been updated for 2009-2010 based on price rises during this period, using Fisher Price indices. The State-wise rural-urban price differential for 2009-2010 has been applied on State-specific urban poverty lines in order to get State-specific rural poverty lines. The head count ratio (HCR) is obtained using urban and rural poverty lines, which have been applied to the MPCE distribution of the States. The aggregated BPL population of the States has been used to obtain the final all-India $\mathrm{HCR}$ and poverty lines in rural and urban areas.
} 


\subsection{Individual respondents}

Of 179 individual respondents directly associated with trading by India with Bangladesh and Pakistan, the survey found 49 per cent respondents were skilled while 42 per cent and 9 per cent were semi-skilled and unskilled, respectively (figure 6). Therefore, the respondents were assumed to be relatively aware of the need for, and benefits of trade facilitation in India.

\section{Figure 6. Skill composition of individual respondents}

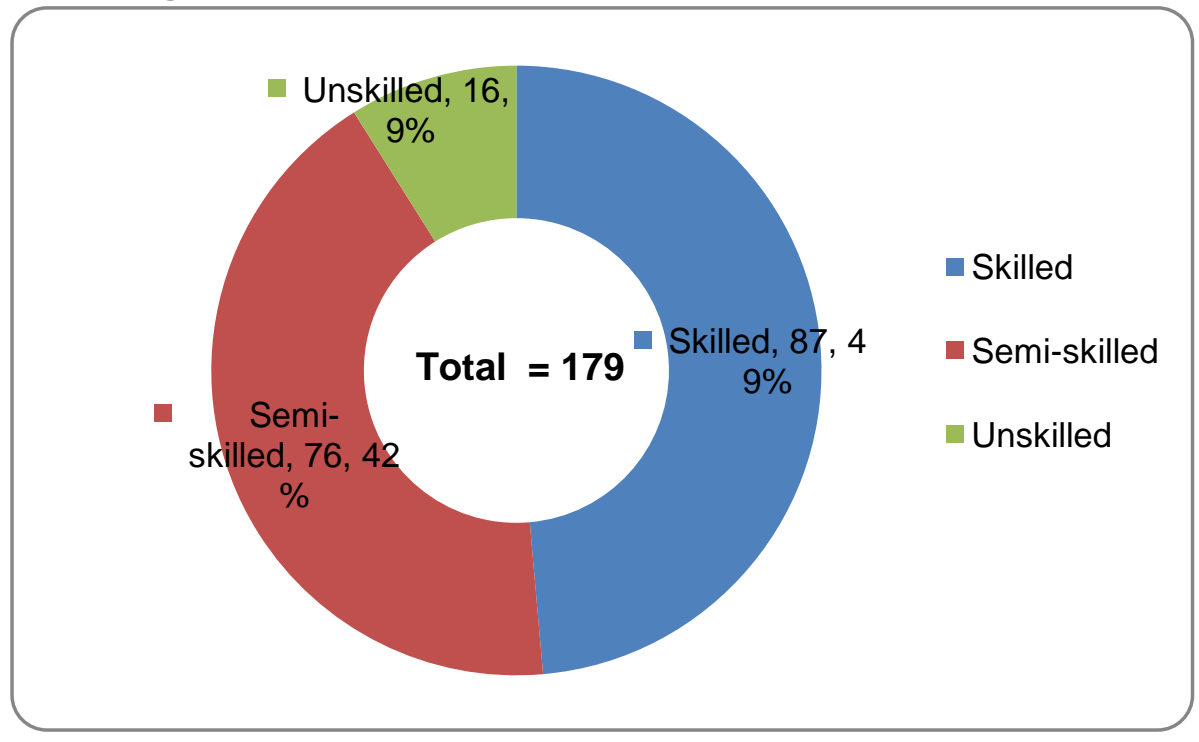

Note: Sample size is in absolute number, and share is in percent

\subsubsection{Quality of trade infrastructure}

The majority of the respondents said trade infrastructure such as customs and transport had improved over time. However, compared to customs and transport, the performance of banks, hotels and restaurants, servicing facilities and communication facilities were way behind the average (figure 7). The perception of the respondents also indicated further scope for improvement in trade facilitation.

\subsubsection{Quality of governance}

The perception of the respondents revealed a mixed result for quality of governance (figure 8). The opinion of individual respondents was that trade along SC 1 had not been disturbed by local mafia, cheating and fraud, or religious tensions. These aspects, therefore, cannot be termed as barriers to trade. However, trading faces major security issues. Strikes and closedowns do happen, but they are not a major issue. 
Figure 7. Opinion of respondents about quality of trade infrastructure
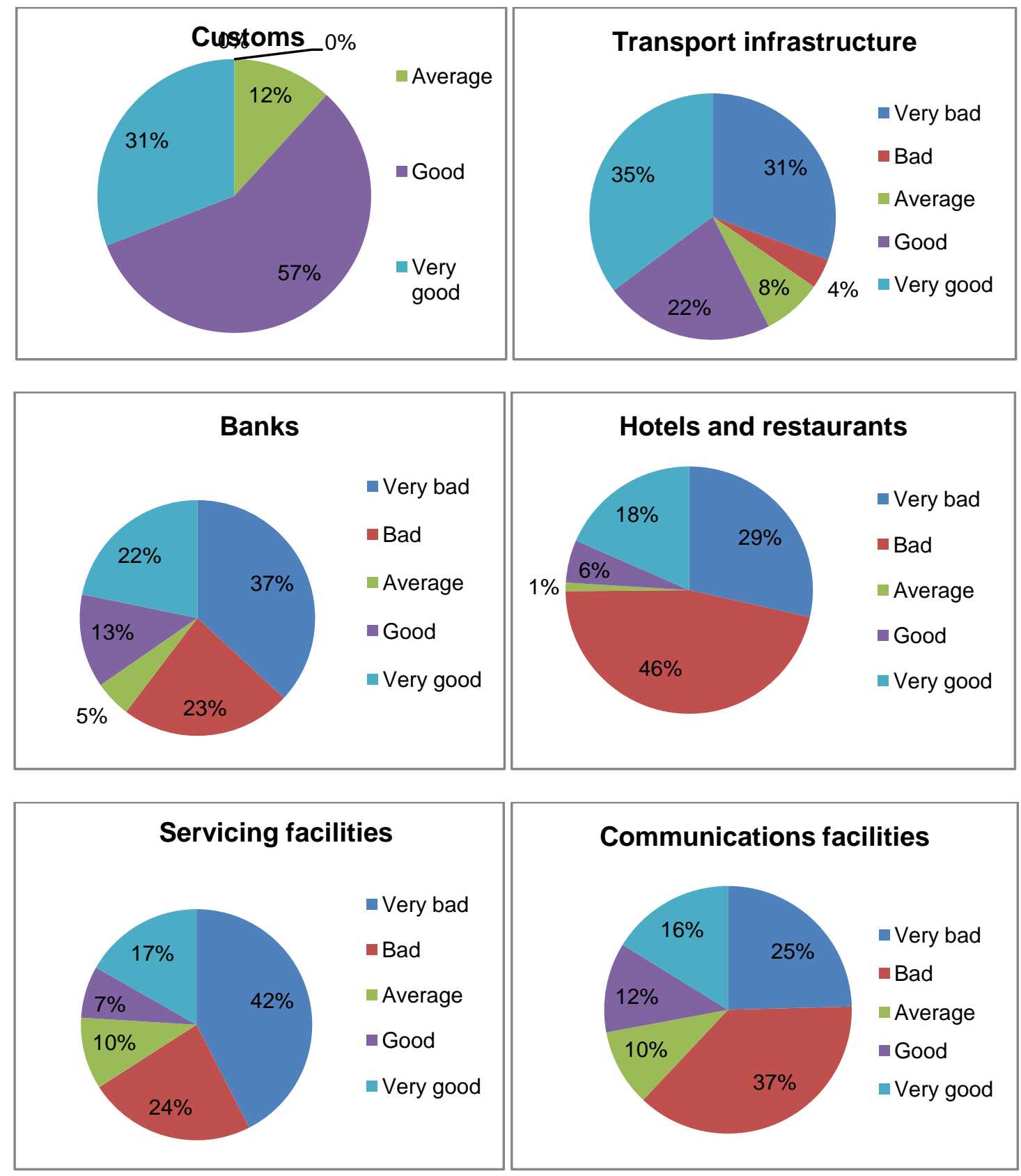
Figure 8. Opinion of individual respondents on governance
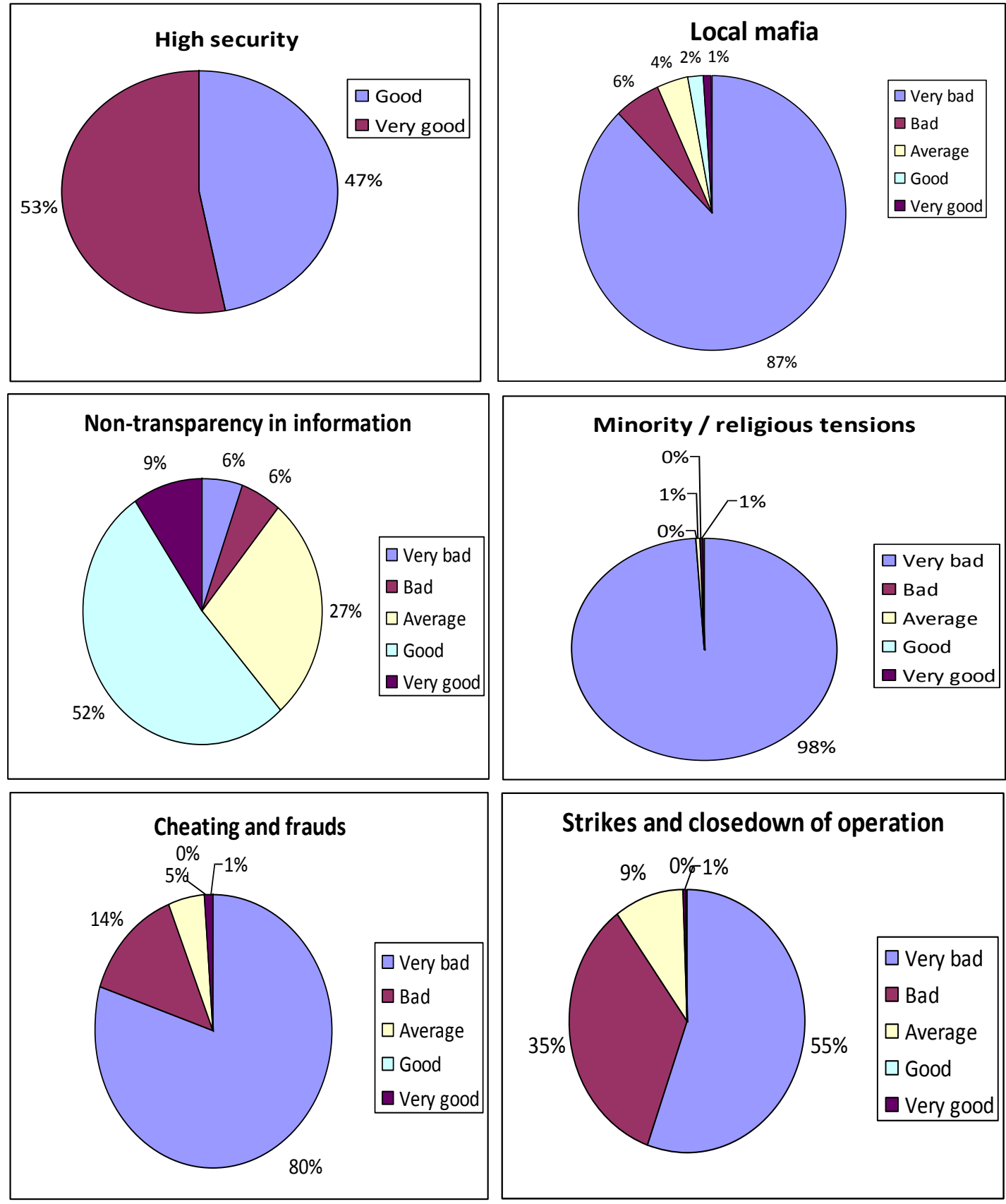

\subsubsection{Individual perceptions about trade barriers}

All the respondents agreed that better trade would reduce poverty through the creation of more jobs, higher skill levels, better income opportunities and higher local production, among other positive advances. Thus, more extensive border trade was perceived by the local populations as reducing poverty in the dimensions mentioned above. The present survey thus attempted to find out, from the perspective of local individuals, what the most important 
barriers were to increasing border trade between India and Pakistan as well as between Pakistan and Bangladesh.

The methodology used for the survey was a detailed questionnaire that was given to 179 individuals connected with the border trade process. The respondents were asked about their types of job (either skilled or unskilled), their experience and their annual income. All these variables were taken as control variables. On the other hand, the perception of the individuals was ranked on a scale of 1 to 5 , with 1 representing the highest barrier and 5 as the least barrier. The following categories of variables were taken as acting as barriers to trade (hence, obstacles to poverty reduction through trade):

(a) A lack of infrastructure, i.e., customs, transport, banks, hotels and restaurants, servicing facilities, communication;

(b) A lack of governance, i.e., security, mafia presence, non-transparency in information, cheating and strikes.

Table 6. Marginal effects in elasticity of Ordered Probit Regression (Calculated at mean values)

\begin{tabular}{lccc}
\hline Variables & $\begin{array}{c}\text { Skill } \\
\text { levels }\end{array}$ & Experience & $\begin{array}{c}\text { Annual } \\
\text { income }\end{array}$ \\
\hline Customs & 0.0730 & -0.2238 & $0.1978^{* *}$ \\
Transport & -0.0453 & 0.0374 & -0.0424 \\
Banks & -0.1446 & -0.0716 & 0.1411 \\
Hotels & 0.0645 & -0.2767 & $0.2609^{* *}$ \\
Servicing facilities & -0.2052 & -0.3206 & 0.1744 \\
Communication & -0.2171 & $-0.3736^{*}$ & 0.1734 \\
Lack of security & 0.2607 & 0.0760 & 0.0328 \\
Mafia dominance & $4.4633^{* * *}$ & -1.6234 & -0.4178 \\
Lack of transparent & $-2.0745^{* * *}$ & $-0.5506^{*}$ & 0.1208 \\
information & & & \\
Cheating in transactions & $4.0489^{* * *}$ & 0.2563 & -0.3357 \\
Strikes by workers & $-2.1594^{* *}$ & -0.0024 & -0.4132 \\
\hline Notes: Tha The
\end{tabular}

Notes: (a) The values are the changes in probability of having an outcome value of 5 in the ranking of the respective categorical variables. Thus, a negative sign indicates less area under that value in the probability of outcome curves, and opposite for a positive sign;

(b) The values are all elasticities, and a value greater than 1 indicates elastic and less than 1 implies inelastic;

(c) The asterisks denote significance levels, with ${ }^{*}=10$ per cent, ${ }^{* *}=5$ per cent and $^{* \star *}=1$ per cent significance

Although the survey involved a total of 179 respondents, the observations of only 143 were actually used since the remaining respondents provided incomplete responses or, in some cases, indicated income levels that were too high. An Ordered Probit Regression analysis was made of the categorical variables on which the ordered responses were received. The main purpose of the study was not to deliberate on the coefficients of the regression but on 
the resulting marginal effects that showed the shift of the underlying probability distribution consequent upon change in the levels of some of the control variables. The aim was to get an estimate of the degree and sign of change in the perception of those individuals who considered the respective barrier to be the least problematic. Table 6 summarises the Ordered Probit regression results.

With regard to infrastructure barriers to trade, surprisingly none of the independent variables affect the outcome probabilities significantly, except for (a) income, which affects customs and hotels; and (b) experience, which affects communications. Those with higher incomes considered customs and hotels to be lesser barriers. The respondents with more extensive experience in their jobs considered communications to be more of a barrier. Other values were not significant. Thus, perceptions of individuals about possible barriers were not significantly related to either skill levels or experience, or even income levels, except in just three cases. Further, the changes were not elastic, signifying a less dramatic response to changes in the control variables.

With regard to governance-related issues, the skills variable is the most important. People with more skills are likely to consider mafia dominance as well cheating as less of a problem. Also, they consider a lack of transparent information and strikes by workers as more of a hindrance to trade. These are all highly significant effects. At the same time, they are highly elastic, signifying dramatic change in perception as a person moves up the skills ladder. Experience significantly affects the perception of a lack of transparent information as a possible barrier. Income levels do not affect perception significantly in these categories.

Looking at table 6, it can be seen that the type of job, i.e., skilled or less skilled, matters most in the formation of differential perceptions about barriers. Thus, a loader on a truck or a restaurant worker view mafia and cheating as hindering the trade more compared with the perception of a clearing agent or exporter. Although this may appear disturbing it could point towards a nexus between the latter and mafia and cheating practices. However, this can only be established conclusively by larger and focused surveys. Experience in terms of the number of years worked does matter, as the more experienced respondents complained more about the lack of both communications and transparency in information.

Surprisingly, income levels play a comparatively moderate role. People with either higher or lower incomes did not differ much in perception except with regard to customs and hotels. Thus, the poor and the wealthy connected with trade in the border areas, indicated relatively similar views of trade barriers. All the respondents believed that trade would reduce poverty 
through the creation of more jobs and skills as well as more local production, and those at the bottom of the income scale did not view possible trade barriers any differently from those at the top of the scale. Therefore, poverty reduction, in the perception of the individuals connected with trade along SC 1, depends on the reduction of trade barriers through better trade facilitation. The type of trade facilitation that may help in reducing poverty does not appear to differ according to whether a person is wealthy or poor.

\subsubsection{Opinions about trade, trade facilitation and poverty reduction}

When asked whether trade was one of the responsible factors in reducing poverty, 59 per cent of the respondents agreed (figure 9). However, the other 41 per cent felt that trade had not succeeded in reducing poverty. Therefore, in an attempt to understand whether or not the opinions of respondents regarding trade facilitation showed any relationship with poverty reduction, a Logit regression was employed to assess this point. There are two issues: (a) trade reduces poverty; and (b) trade facilitation accelerates trade. In a logistic regression, both cannot be there in the Odds Ratio. Assuming that the second issue is true by definition, the logic of transitivity implies an Odds Ratio in terms of whether individuals or firms believe trade reduces poverty allows the binary variable (trade reduces poverty, where $1=$ Yes and 0 $=$ No) can be regressed on categorical variables that are entirely trade facilitation variables. Thus, it is possible to answer the question of whether it is likely, from the perception of those who are involved in cross-border trade, that trade facilitation will reduce poverty. ${ }^{24}$

\section{Figure 9. Opinion of respondents on role of trade in poverty reduction}

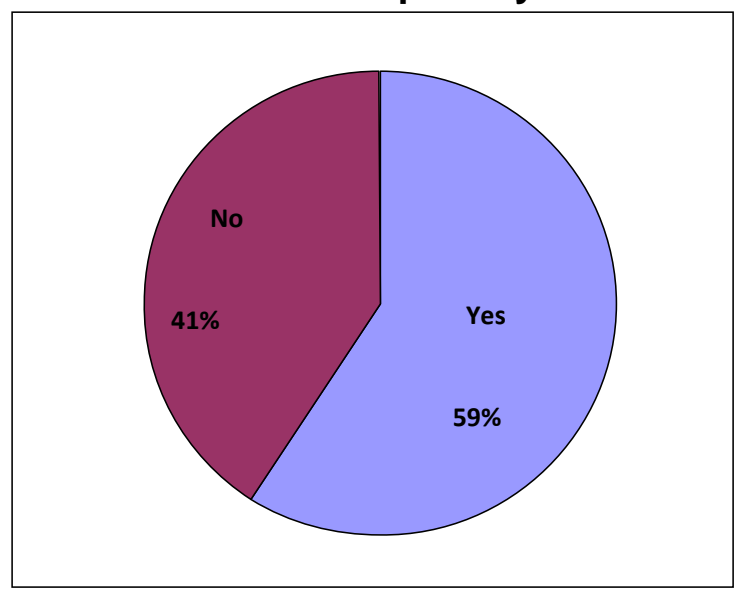

\footnotetext{
${ }^{24}$ A Logit analysis based on perception survey is not historical in nature. However, the significance of predictions is checked based on such surveys. Hence, in a sense it cannot be a prediction based on historical time-series or panel data. On the other hand, since this study takes the approach that higher trade facilitation promotes more trade, the Logit analysis does show a direct link between trade facilitation and poverty reduction.
} 
The Odds Ratio in the Logit regression is the probability that trade has reduced poverty. The independent variables are category ranking responses on a scale of 1 to 5 regarding the perception of barriers to trade by individuals. A value of 5 implies a low barrier of the concerned variable and 1 implies a high barrier. Thus, the sign of the coefficients of the regression implies how a one unit change in the explanatory category variable affects the Odds Ratio.

Table 7. Logit regression results (individuals): Trade facilitation to reduce poverty (DV = Log of Odds Ratio by which poverty is reduced)

\begin{tabular}{|c|c|}
\hline Variables & Estimated coefficient \\
\hline \multirow[t]{2}{*}{ Better customs } & $-2.488^{\star \star \star}$ \\
\hline & $(1.853)$ \\
\hline Better transport infrastructure & $\begin{array}{c}-1.801^{* * *} \\
(0.360)\end{array}$ \\
\hline More banks & $\begin{array}{c}0.677^{*} \\
(0.493)\end{array}$ \\
\hline \multirow[t]{2}{*}{ More hotels and restaurants } & -0.324 \\
\hline & $(0.779)$ \\
\hline \multirow[t]{2}{*}{ Better servicing facilities } & $1.387^{\star *}$ \\
\hline & $(0.883)$ \\
\hline Better communications facilities & $\begin{array}{c}-0.0737 \\
(0.786)\end{array}$ \\
\hline Higher security & $\begin{array}{l}-1.732^{*} \\
(0.933)\end{array}$ \\
\hline \multirow[t]{2}{*}{ Less local mafia } & $-1.163^{\star *}$ \\
\hline & $(0.490)$ \\
\hline \multirow[t]{2}{*}{ More transparency in information } & $1.015^{\star \star}$ \\
\hline & $(0.577)$ \\
\hline \multirow[t]{2}{*}{ Less cheating } & $1.541^{* \star}$ \\
\hline & $(0.735)$ \\
\hline \multirow[t]{2}{*}{ Fewer strikes/closedowns of operatior } & -0.586 \\
\hline & $(1.203)$ \\
\hline \multirow[t]{2}{*}{ Constant } & $19.561^{* * *}$ \\
\hline & $(12.145)$ \\
\hline Observations & 175 \\
\hline Pseudo $\mathrm{R}^{2}$ & 0.619 \\
\hline Wald $\operatorname{chi}^{2}(11)$ & 113.26 \\
\hline Prob > chi ${ }^{2}$ & 0 \\
\hline
\end{tabular}

Table 7 presents the Logit regression results. It can be seen that in the perception of individuals, only four trade barriers (or facilitation) variables affect the reduction of poverty, 
i.e., banks, servicing facilities, more transparency in information and less cheating in transactions. These are all statistically significant variables. However, better facilitation in terms of infrastructure variables such as customs or transport, and governance variables such as local mafia or high security does not appear to be important in increasing the probability of a positive response regarding poverty reduction. The usual caveat is that the Logit regression result needs deeper introspection. In other words, in the view of individuals engaged in trade along SC 1, trade facilitation alone may not create opportunities for poverty reduction.

\subsection{Opinions of firms}

Interviews were held with 100 Indian firms doing business with Pakistan and Bangladesh, mostly located along SC 1 in places such as Amritsar, Ludhiana and Kolkata, of which 58 per cent are trading with Bangladesh, 21 per cent with Pakistan and the remaining 21 per cent with other countries such as Afghanistan, Central Asia, the Middle East and Gulf States, Europe and East Asia (figure 10). As of March 2012, the interviewed firms had generated direct employment of 32,820 people, of whom 89 per cent were skilled employees and remainder unskilled (figure 11). The surveyed firms were exporting and importing various goods, including agricultural products, via SC 1. Such goods pass through Attari-Wagah (trade with Pakistan) and Petrapole-Benapole (trade with Bangladesh). ${ }^{25}$

Figure 10. Distribution of firms in terms of trading partners

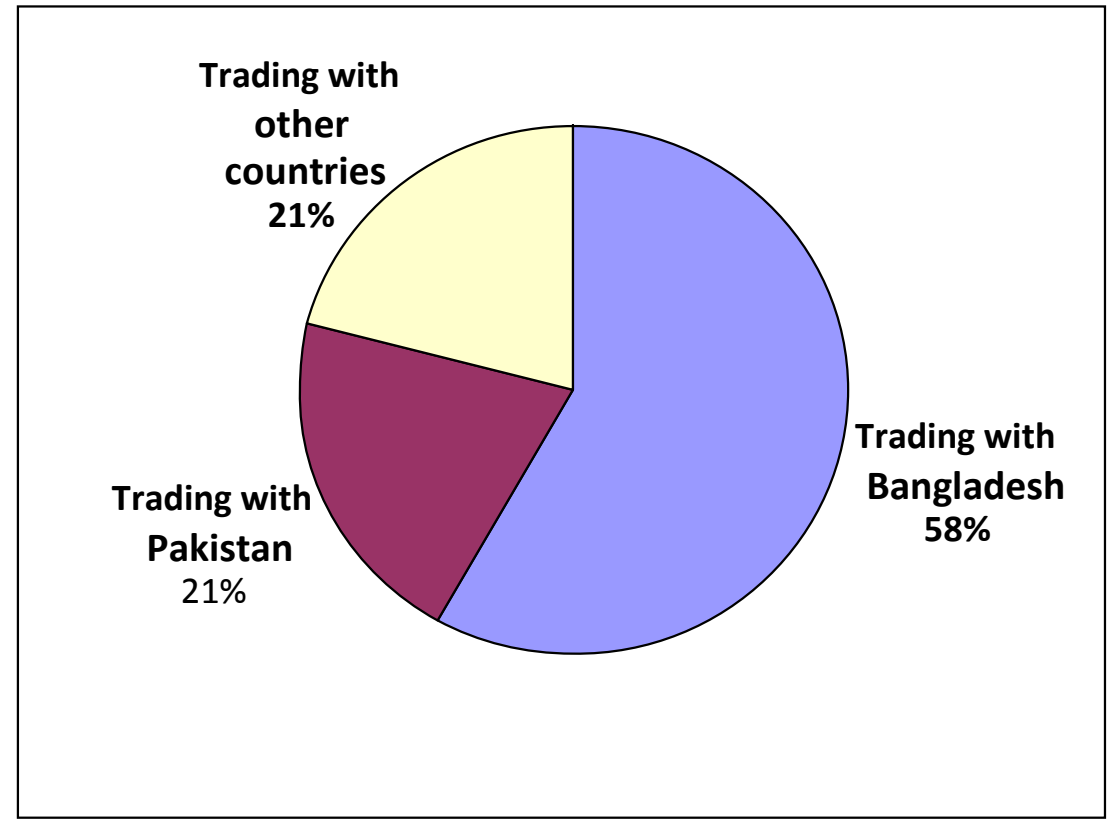

${ }^{25}$ These traded items are not discussed here as that is beyond the scope of this study. However, a list of such items is available on request. 


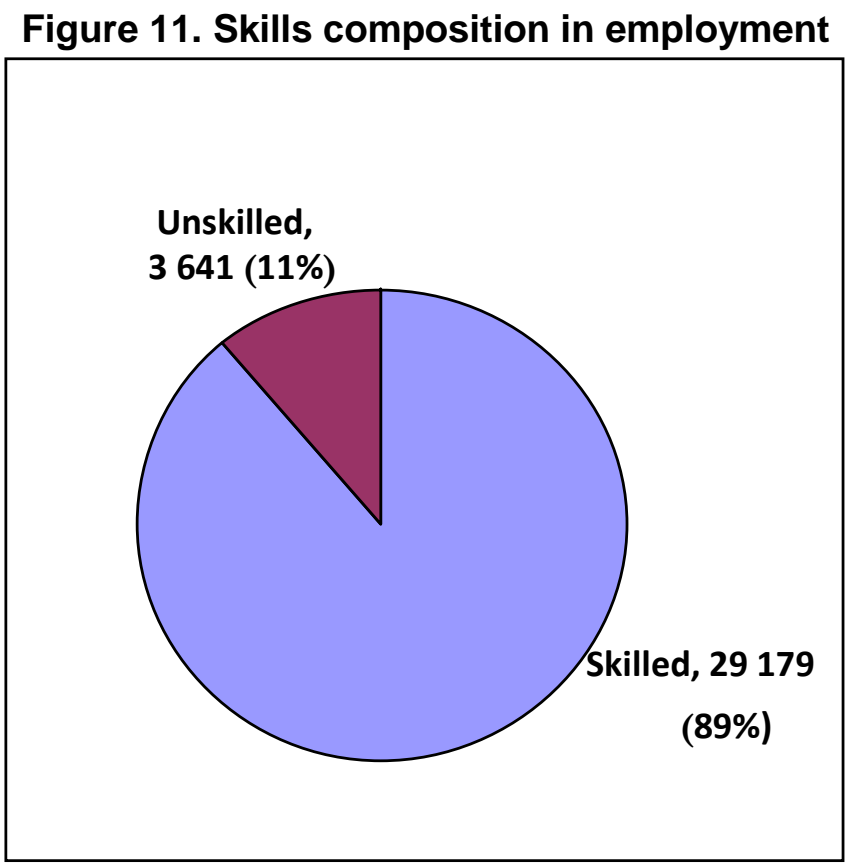

\subsubsection{Availability of trade infrastructure}

Table 8 presents the perception of the surveyed firms concerning the availability of trade infrastructure. All the firms felt that dispute settlement arrangements and weigh bridge facilities were available. However, regarding the availability of the remaining facilities and services, perception varied across firms. While only 10 per cent of the respondents said container handling equipment was available (90 per cent disagreed with this perception), 33 per cent firms said telephone facilities were not available (67 per cent disagreed with this view). Nonetheless, all the firms said some facilities were not available at all such as transit services, fast track cargo clearance, post offices, waiting rooms, health facilities and banks.

\subsubsection{Opinions about logistics costs in SC 1}

While the opinions of the majority of respondents indicated port and airport charges in India were high, a large majority suggested that the rate of road and rail transportation charges as well as warehouse and loading service charges were average (figure 12). Thus, logistics costs (domestic) are a critical factor in facilitating trade with Bangladesh and Pakistan. 
Table 8. Physical and non-physical trade barriers at Indian borders with Bangladesh and Pakistan*

(a). Availability of facilities

\begin{tabular}{lc}
\hline Availability & Perception (\%) \\
\hline Weigh bridge & 100 \\
Dispute settlement & 100 \\
Telephone & 67 \\
Customs & 56 \\
Security & 56 \\
Container handling yard & 56 \\
Standards (customs) & 56 \\
Internet & 46 \\
Shops, hotels and restaurants & 36 \\
Immigration & 33 \\
Warehouse and parking & 33 \\
E-commerce of customs & 23 \\
Currency exchange & 23 \\
Container handling equipment & 10 \\
\hline
\end{tabular}

(b). Non-availability of facilities

\begin{tabular}{lc}
\hline Non-availability & $\begin{array}{l}\text { Perception } \\
\text { (\%) }\end{array}$ \\
\hline Banks & 100 \\
Health facilities & 100 \\
Waiting rooms & 100 \\
Post offices & 100 \\
Fast track cargo clearance & 100 \\
Transit & 100 \\
\hline${ }^{*}$ Border check posts/land customs stations only on SC 1.
\end{tabular}


Figure 12. Opinions on operational logistics costs
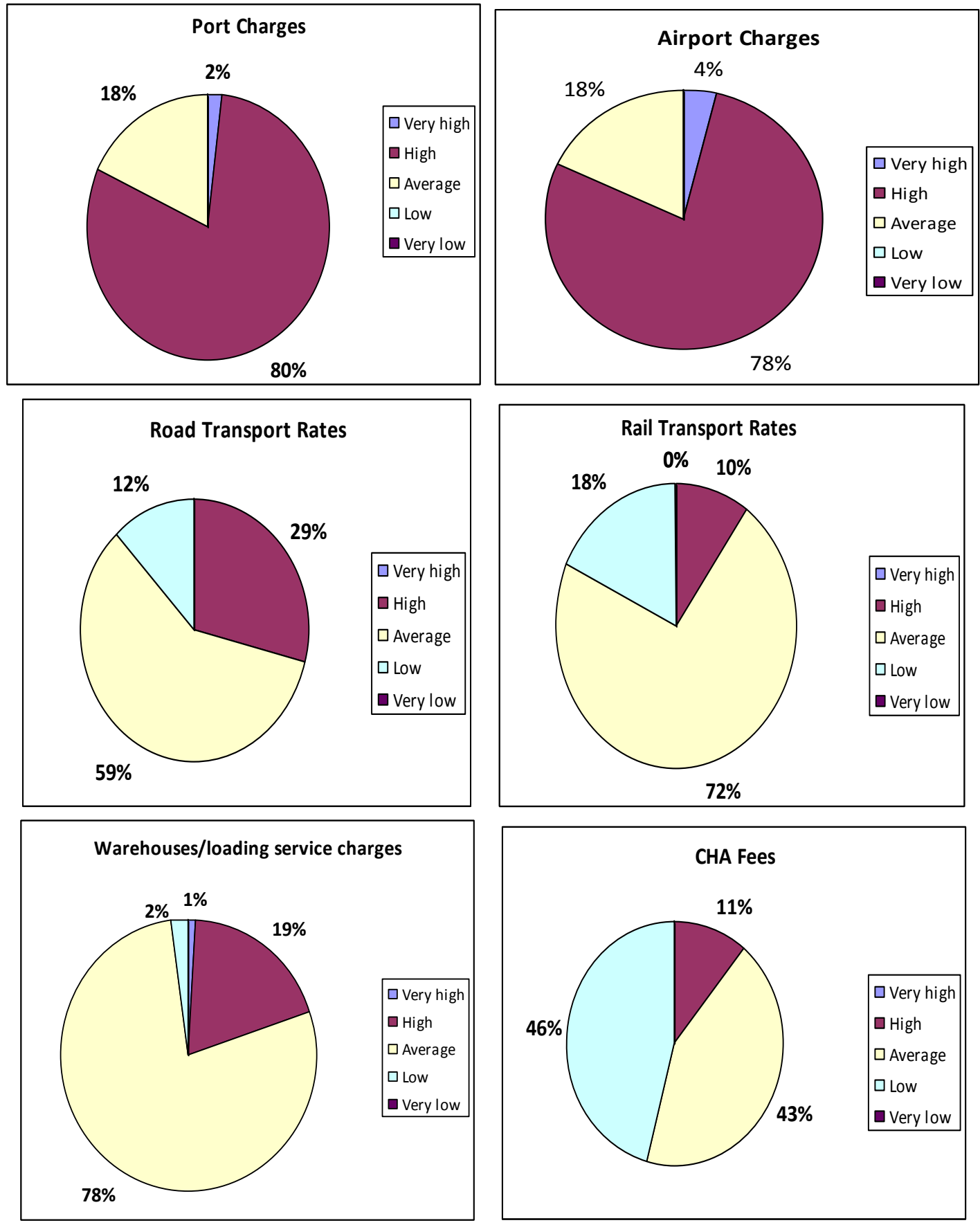

\subsubsection{Transaction time at border}

The opinions of firms indicate that the processing of India's exports to Pakistan take a shorter time at the border compared with India's exports to Bangladesh. According to 97 per cent of the respondents, India's exports to Pakistan take one day without physical inspection, while 88 per cent of the respondents said processing required two days with physical inspections (table 9). 
However, the results were mixed for Indian exports to Bangladesh. Although 66 per cent of the firms said Indian exports to Bangladesh took one day with or without a physical inspection, 27 per cent said it took two days without physical inspection. At the same time, about 7 per cent and 22 per cent of the respondents said it took three days at the border without and with physical inspections, respectively.

Table 9. Border transaction times

(a). Indian exports to Pakistan

\begin{tabular}{lcc}
\hline Time & $\begin{array}{c}\text { Without } \\
\text { physical } \\
\text { inspection }\end{array}$ & $\begin{array}{c}\text { With } \\
\text { physical } \\
\text { inspection }\end{array}$ \\
\hline 1 day & 97 & - \\
2 & 3 & - \\
days & & 12 \\
1 day & - & 88 \\
2 & - & \\
days & & \\
\hline
\end{tabular}

(b). Indian exports to Bangladesh (Unit: Per cent)

\begin{tabular}{lcc}
\hline Time & $\begin{array}{c}\text { Without } \\
\text { physical } \\
\text { inspection }\end{array}$ & $\begin{array}{c}\text { With physical } \\
\text { inspection }\end{array}$ \\
\hline 1 day & 66 & - \\
2 days & 27 & - \\
3 days & 7 & - \\
1 day & - & 66 \\
2 days & - & 12 \\
3 days & - & 22 \\
\hline
\end{tabular}

\subsubsection{Perception of customs process}

The perception among firms regarding the customs process was mixed. As shown in table 10, about 77 per cent of the respondents said they were unaware of being able to complete customs declarations online, whereas all the respondents said customs does not:

(a) Allow pre-arrival clearance of merchandise/shipments for imports:

(b) Use post clearance audit for imports:

(c) Allow traders (or their agents) to choose the location of the final clearance of goods for imports: 
(d) Allow goods to be released pending final clearance against an accepted guarantee.

At the same time, all the firms said that the customs code required importers to use a licenced customs broker to clear goods, Customs does interact formally to discuss about policy, and receive advance notification of binding changes with regard to tariff classification, valuation or rules of origin from customs. In addition, about 35 per cent of the respondents were unaware of the availability of a review/appeal procedure in cases of disputes with Customs.

Table 10. Perception about customs processing at border crossings

\begin{tabular}{|c|c|c|c|}
\hline & & & Unit: Per cen \\
\hline & Yes & No & Do not know \\
\hline Can a customs declaration be submitted online? & 23 & 77 & \\
\hline $\begin{array}{l}\text { Does customs allow for pre-arrival clearance of } \\
\text { merchandise/shipments for import? }\end{array}$ & & 100 & \\
\hline $\begin{array}{l}\text { Does the custom code require importers to use a } \\
\text { licenced custom broker to clear goods? }\end{array}$ & 100 & & \\
\hline $\begin{array}{l}\text { Does customs use a post-clearance audit for } \\
\text { imports? }\end{array}$ & & 100 & \\
\hline $\begin{array}{l}\text { Are you and your customers able to choose the } \\
\text { location of the final clearance of goods for imports? }\end{array}$ & & 100 & \\
\hline $\begin{array}{l}\text { Can goods be released pending final clearance } \\
\text { against an accepted guarantee? }\end{array}$ & & 100 & \\
\hline $\begin{array}{l}\text { Are you and your peers invited for dialogue by } \\
\text { Customs through a formal process (periodic } \\
\text { meetings, consultative forums or committees etc.)? }\end{array}$ & 100 & & \\
\hline $\begin{array}{l}\text { In cases of disputes with customs or other border } \\
\text { agencies, is a review/appeal procedure available? }\end{array}$ & 65 & & 35 \\
\hline $\begin{array}{l}\text { Do you receive advance notification of binding } \\
\text { changes with regard to tariff classification, valuation } \\
\text { or rules of origin? }\end{array}$ & 100 & & \\
\hline
\end{tabular}

\subsubsection{Trade barriers identified by Indian exporters and importers}

During the survey, 40 per cent of the interviewed firms identified some barriers that they had faced while exporting and importing with Bangladesh and Pakistan. Tables 11(a) and 11(b) contain lists of barriers and relevant regulators. These barriers are a mixture of physical and non-physical bottlenecks, and cover many issues ranging from the repair and development of roads and highways to slow access to the Electronic Data Interchange (EDI) system. Subnational cases such as value-added tax (VAT) were also identified as a barrier to trade. 
Although cheaper, rail is time-consuming because

(a) absence of wrecks, and (b) availability of equal numbers from both sides for exchange.

2 Traders are afraid to send cargo by rail because of drug incidents.

3 A bank is only in Amritsar Town. There are no banks in or near Attari ICP.

4 Imported crude drugs get wet in the rain as there are not enough sheds to accommodate the cargo.

5

Storage space made for trade but used by Border Security Force (BSF) for their accommodation.

6 Products are taken away by customs as samples, thereby causing shortages of merchandise.

$7 \quad$ Both weighing bridges at Attari ICP are defective.

8 Free trade through Kashmir is affecting trade at Attar.

$9 \quad$ VAT in Punjab is 1 per cent higher than in adjoining States making products uncompetitive.

10 Contract registration required for exporting cotton yarn is valid for only 30 days. If export is not made in time a penalty of Rs 10,000, or 1 per cent of value is incurred, whichever is higher.

11 Insufficient space, so less time available for loading and unloading of vessels.

12 Road conditions in Ludhiana are very bad.

13 Machinery at Ludhiana dry ports is very old.

14 Gateway ports are very congested.

15 Exporters and importers prefer forwarders in lieu of carriers as they give credit.

16 Strikes at ports disturb the entire chain.

17 Policies related to exporting changes frequently, which puts exporters in a bad position with customers.
Railways

Customs

Banks

Storage and
warehousing
(CWC)

Security and storage and warehousing

Customs

Highways

Customs, Directorate-General of Foreign Trade (DGFT)

Punjab

Government

DGFT

Shipping

Highways, Punjab Government

Railways

Shipping

Banks, customs

Labour, shipping

Commerce 
Table 11(b). Trade barriers faced by Indian exporters and importers with Bangladesh

\begin{tabular}{|c|c|c|}
\hline Sr. No. & Types of barriers & Authority/subject \\
\hline 1 & $\begin{array}{l}\text { Policies related to export changes frequently puts firms } \\
\text { in a bad position with customers. }\end{array}$ & Commerce \\
\hline 2 & Frequent strikes at port. & Labour, shipping \\
\hline 3 & VAT is high. & $\begin{array}{l}\text { West Bengal } \\
\text { Government }\end{array}$ \\
\hline 4 & $\begin{array}{l}\text { If cargoes miss a vessel then the next ship is available } \\
\text { after a week. Traders have to bear daily port charges } \\
\text { and give discounts to customers. Roll-over charges are } \\
\text { also expensive. }\end{array}$ & Ports \\
\hline 5 & EDI system of customs is very slow. & Customs \\
\hline 6 & $\begin{array}{l}\text { The number of shipping lines sailing to Bangladesh is } \\
\text { steadily declining. Previously there were five shipping } \\
\text { lines; this figure is now only two shipping lines today } \\
\text { (APL and NYK). }\end{array}$ & Shipping \\
\hline 7 & Shortage of electricity. & Power \\
\hline 8 & EDI system of customs is slow. & Customs \\
\hline 9 & The United States dollar exchange rate is high. & Finance, RBI \\
\hline 10 & $\begin{array}{l}\text { High labour rate at CWC (Rs.3000) whereas outside } \\
\text { labour rate is Rs } 1,500 .\end{array}$ & CWC \\
\hline 11 & $\begin{array}{l}\text { Private parking is Rs } 50 \text { per day and Rs } 80 \text { per day at } \\
\text { the CWC warehouse, }\end{array}$ & CWC \\
\hline 12 & $\begin{array}{l}\text { A Bangladesh warehouse can accommodate } 300-400 \\
\text { trucks, whereas in India 80-100 trucks can be } \\
\text { accommodated. }\end{array}$ & CWC \\
\hline 13 & $\begin{array}{l}\text { There are no online document exchange facilities } \\
\text { between India and Bangladesh. }\end{array}$ & DGFT, customs \\
\hline 14 & $\begin{array}{l}\text { Ghojadanga LCS has no phytosanitary and quarantine } \\
\text { office. }\end{array}$ & Customs \\
\hline 15 & No bank at Ghojadanga LCS. & Bank \\
\hline 16 & No warehouse at Ghojadanga LCS. & CWC \\
\hline 17 & No government parking at Ghojadanga LCS. & CWC \\
\hline 18 & No import through Ghojadanga LCS. & DGFT \\
\hline 19 & $\begin{array}{l}\text { Bridge leading to Ghojadanga border is damaged, so } \\
\text { heavy trucks ( } 10 \text { wheels and above) are not allowed. }\end{array}$ & Highways \\
\hline
\end{tabular}

\subsubsection{Opinions of firms about trade facilitation and poverty}

In the survey, about 86 per cent of the respondents said poverty had declined during the past five years, 72 per cent of whom felt India's trade with India and Pakistan was one of the major factors responsible for the reduction of poverty (figure 13). The survey therefore attempted 
with the help of Logit regression to assess whether or not there was any empirical relationship between trade facilitation and poverty reduction from the perspective of exporters and importers.

Figure 13. Perception about poverty and trade facilitation
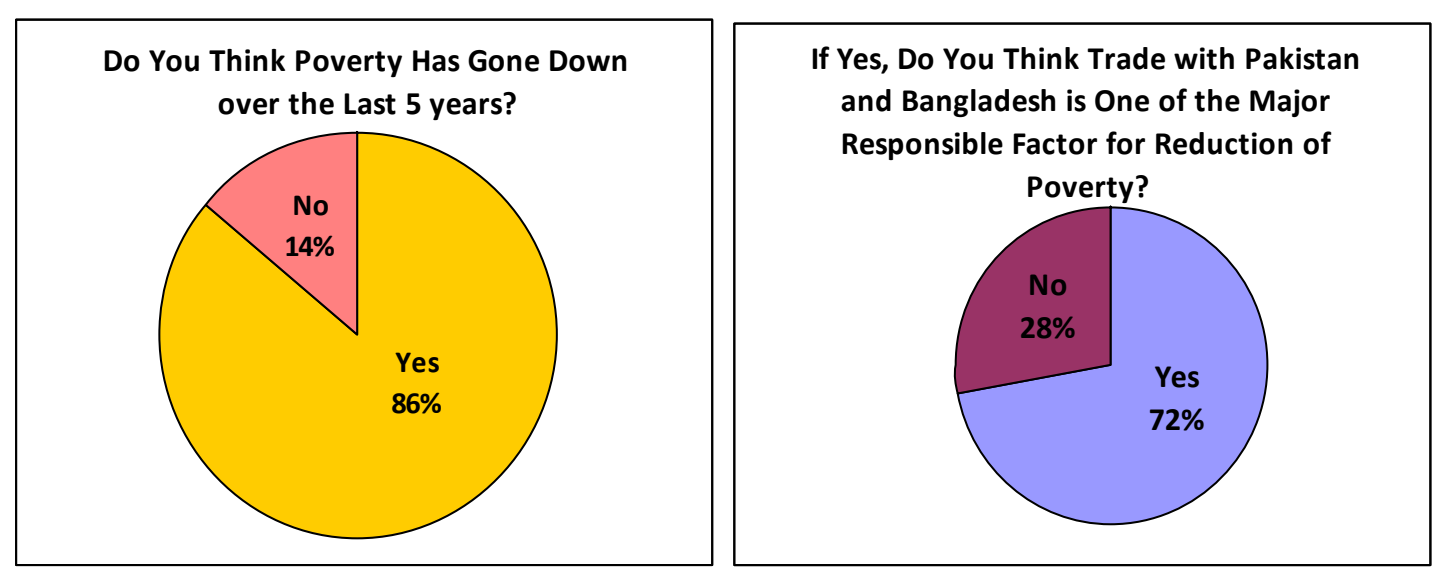

Table 12. Logit regression results (firms):

Reduction of poverty by trade facilitation

(DV = Log of Odds Ratio by which poverty is reduced)

\begin{tabular}{lc} 
Variables & $\begin{array}{c}\text { Estimated } \\
\text { coefficients }\end{array}$ \\
\hline Better infrastructure at checkpoints & $9.59^{\star * *}$ \\
Better transportation infrastructure & $(1.413)$ \\
for accessing checkpoints & $31.70^{\star * *}$ \\
Better telecommunications & $(1.552)$ \\
infrastructure at checkpoints & $-6.76^{* * *}$ \\
Less bureaucracy and red-tape at & $(0.518)$ \\
checkpoints & $47.09^{* * *}$ \\
Less corruption and bribery at & $(2.863)$ \\
checkpoints & $-15.87^{\star * *}$ \\
Faster handling equipment & $(1.035)$ \\
& $27.96^{\star * *}$ \\
Less lengthy paper work at & $(1.577)$ \\
checkpoints & $-79.31^{* * *}$ \\
& \\
Observations & $(1.526)$ \\
Pseudo $R^{2}$ & 100 \\
Wald chi ${ }^{2}$ (Prob > chi2) & 0.869 \\
\hline Note: Robust standard errors in parentheses; ${ }^{* * *} \mathrm{p}<0.01,{ }^{* *} \mathrm{p}<0.05$ \\
and ${ }^{*} \mathrm{p}<0.1$.
\end{tabular}


Table 12 presents the Logit regression results. As discussed above, the Logit regression presents the probability that trade has reduced poverty. The opinions of firms towards poverty and trade facilitation are considered here. The independent variables are categorical ranking responses on a scale of 1 to 5 with regard to perception of barriers to trade by the firms. $A$ value of 5 implies the lowest barrier of the concerned variable as in the individual regression while 1 implies a very high barrier. Thus, the sign of the coefficients of the regression implies how one unit changes in the explanatory variable affects the Odds Ratio (outcome variable). It was found that four trade barrier (or facilitation) variables were perceived as affecting reduction of poverty, i.e., less bureaucracy and red-tape, better infrastructure, better transportation and faster handling equipment. These variables are statistically significant at the 1 per cent level. With 87 per cent Pseudo $\mathrm{R}^{2}$, regression is also robust. However, poor border telecommunications infrastructure, less corruption and bribery at checkpoints and lengthy paperwork do not appear to be significantly important in increasing the probability of a positive response regarding poverty reduction.

The results obtained from the survey are quite startling. This may be due to the pooled regression of firms operating at the two borders - Wagah at the India-Pakistan border and Petrapole at the India-Bangladesh border. Although the infrastructure at Wagah has improved considerably in the past few years, the same is not the case at Petrapole. More firms operating on the Bangladesh border believe that poverty has declined despite the inadequate trade-related infrastructure. In the case of governance-related variables, there is not much difference. Thus, poor transportation or inadequate infrastructure may be hampering cross-border trade, especially between India and Bangladesh, but that has not prevented firms from believing that poverty is getting less over time.

With regard to governance-related variables, the survey shows that even if firms believe that less corruption and bribery or less lengthy paperwork may facilitate trade, they have not influenced the firms' perception of poverty reduction. In other words, in general, the perception of firms engaged in trade along SC 1 is that trade facilitation may create opportunities for reduction of poverty. However, the perception is mixed and the connection of the variables to poverty alleviation needs to be clarified through follow-up surveys of the specific variables. Thus, the usual caveat is that the Logit regression result needs more detailed assessment. 


\section{Conclusion}

The major findings of the study are presented in two separate categories - individuals and firms. The majority of the individual respondents noted that trade infrastructure quality such as customs and transport had improved over time. However, compared to customs and transport, the respondents indicated that the performance of banks, hotels and restaurants, servicing facilities and communication facilities were much below average. They also indicated that a there was further scope for improvement in trade facilitation.

However, trading faces the issue of heavy security.

With regard to the quality of trade governance, of the reactions of the individual respondents was mixed. They indicated that trade along SC 1 had not been disturbed by the local mafia, cheating and fraud or religious tension. These issues therefore cannot be termed as barriers to trade in the present context. Although strikes and closedowns occur, they are also not a major issue. However, trading faces the issue of heavy security. The individual respondents all agreed that better trade would reduce poverty through the creation of more jobs, higher skills, better income opportunities and higher local production, among other benefits. Thus, expansion of border trade was perceived as helping to reduce poverty within the dimensions discussed in this study.

Regarding infrastructure barriers to trade, surprisingly none of the independent variables had affected the outcome probabilities significantly with the exceptions of income, which had affected customs and hotels, and experience, which had affected communications. Those with higher incomes considered customs and hotels to be lesser barriers. People with more experience in jobs considered communications as a more significant barrier. Other values were not found to be significant. Thus, the perceptions of individuals about possible barriers were not significantly related to either skill levels or experience, or even income levels, except in just three cases. In addition, the changes are not elastic signifying a less dramatic response to changes in the control variables.

With regard to governance-related issues, it was found that the skills variable was found to be the most important. People with better skills were to be more likely to consider mafia dominance and cheating as less of a problem. Instead, they considered a lack of transparent information and strikes by workers to be more of a problem hampering trade. These are all highly significant effects and are highly elastic, signifying dramatic changes in perception while moving up the skill ladder. Likewise, experience significantly affected the perception of 
a lack of transparent information as a possible barrier. Income levels, however, did not significantly affect perception of these categories.

It can be concluded that the type of job, i.e., skilled or less-skilled, matters most in forming perceptions about barriers. Thus, a loader on a truck or a restaurant worker view mafia and cheating as hampering trade more compared with the perception of a clearing agent or exporter. While this may appear disturbing it might point towards a nexus between the latter and both the mafia and cheating practices; but this can only be confirmed by larger and focused surveys. However, experience, in terms of the number of working years, does matter as the more experienced respondents placed greater emphasis on complains about the lack of communications and transparency in information.

Surprisingly, income levels were found to play a comparatively minor role. Respondents with higher or lower income levels differed little in perception except in the case of customs and hotels. Thus, the poor and the wealthy connected with trading in the border areas had similar views of trade barriers. All believed that trade facilitation reduced poverty through more jobs and skills creation, and increased local production. Thus, in the opinion of those individuals connected with border trade, poverty reduction depended on a reduction of trade barriers through better trade facilitation. Also, whether a respondent was wealthy or poor, there was generally little difference in the perception of the type of trade facilitation that might help to reduce poverty.

On the question of whether trade was one of the factors responsible for the reduction of poverty, 59 per cent of the respondents gave an affirmative reply. However, the other 41 per cent felt that trade had not succeeded to reduce poverty so far. This study shows that in the perception of the individuals, only four trade barriers (or facilitation) variables affect the reduction of poverty, i.e., banks, servicing facilities, more transparency in information and less cheating in transactions. These are all statistically significant. On the other hand, better facilitation in terms of infrastructure variables (such as customs and transportation) and governance variables (such as local mafia or high security) did not appear to be important in increasing the probability of a positive response regarding poverty reduction.

A similar exercise carried out with firms revealed that 86 per cent believed poverty had declined and 72 per cent saw trade as major catalyst for that result. It is important to note that the India-Pakistan border trade infrastructure was found to be much better than that for India-Bangladesh border trade. In terms of governance variables (such as mafia, security and bribery), the difference in perception was much less. However, for the Logit regression to 
assess the link between trade facilitating variables and poverty reduction in the perception of the firms, a pooled regression was taken in order to provide a reasonable sample size. This might have even out the responses to a certain extent. In general, in the perception of the firms, better infrastructure that encouraged more trade was also seen as facilitating a decline in poverty. However, the same was not true with the perception of some governance variables, such as cheating or extensive paperwork requirements.

The pilot survey described here is on cross-border trade. It must be kept in mind that a major proportion of the income earners covered by the survey are employed in unskilled and semi-skilled jobs on an informal contract basis. However, it was almost impossible to get any official historical data about these workers and the analysis was thus unable to progress any further. So, the perception survey appears to be the best alternative. Large-scale surveys spanning a wide region can certainly be an alternative.

The results, for both individual and firms, need more in-depth examination as, in the perception of those firms engaged in trade along SC 1 , simply facilitating more trade may not create opportunities for the reduction of poverty; it may be necessary to do so together with better governance. The perception is mixed and the connection of the perception variables to poverty alleviation needs to be clarified through follow-up surveys that focus on the specific variables. 


\section{Annex 1}

\section{SAARC Highway Corridor 1}

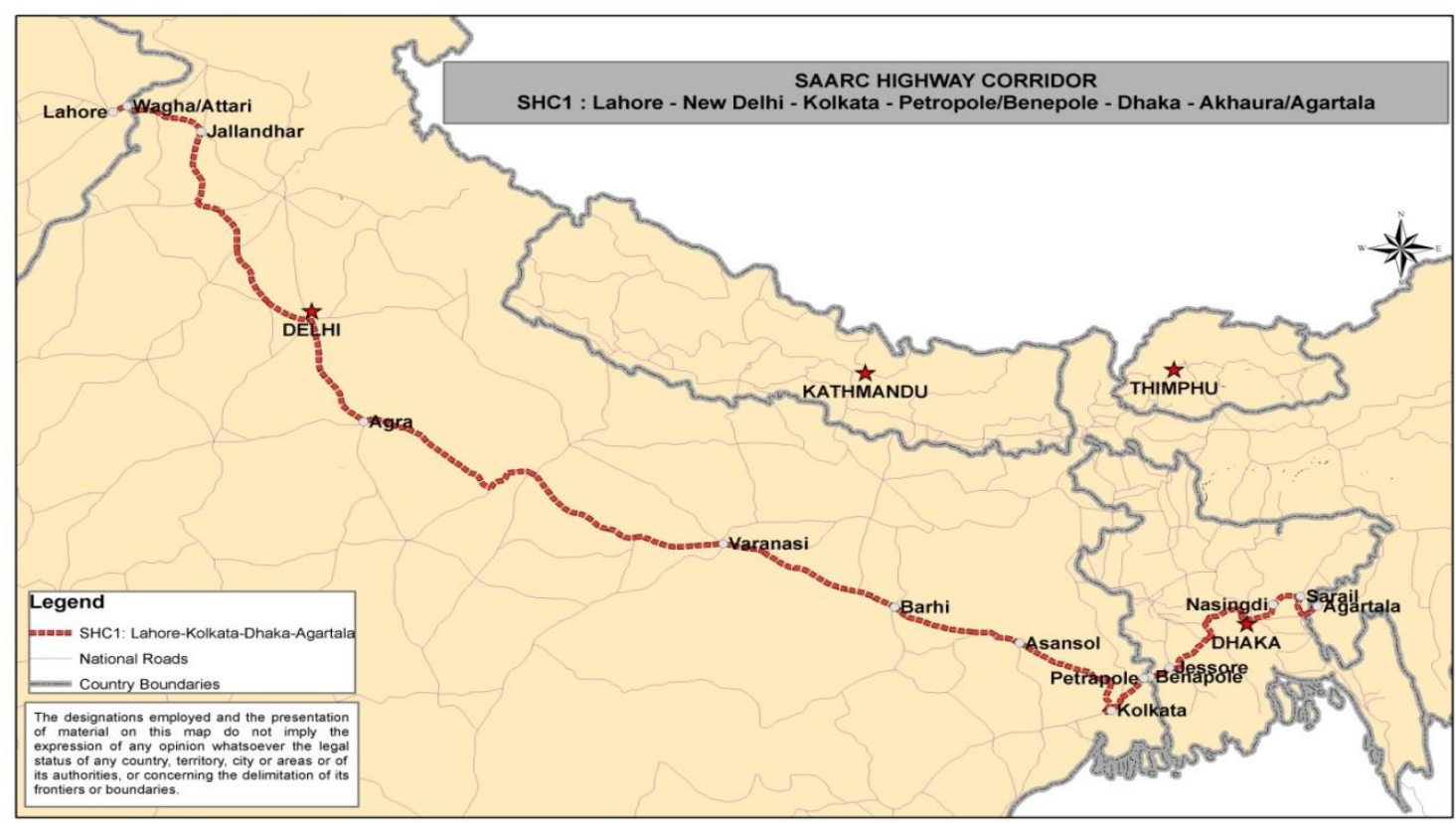

Source: SAARC Secretariat, Kathmandu. 
Annex 2

Trade policy and poverty : Causal connections

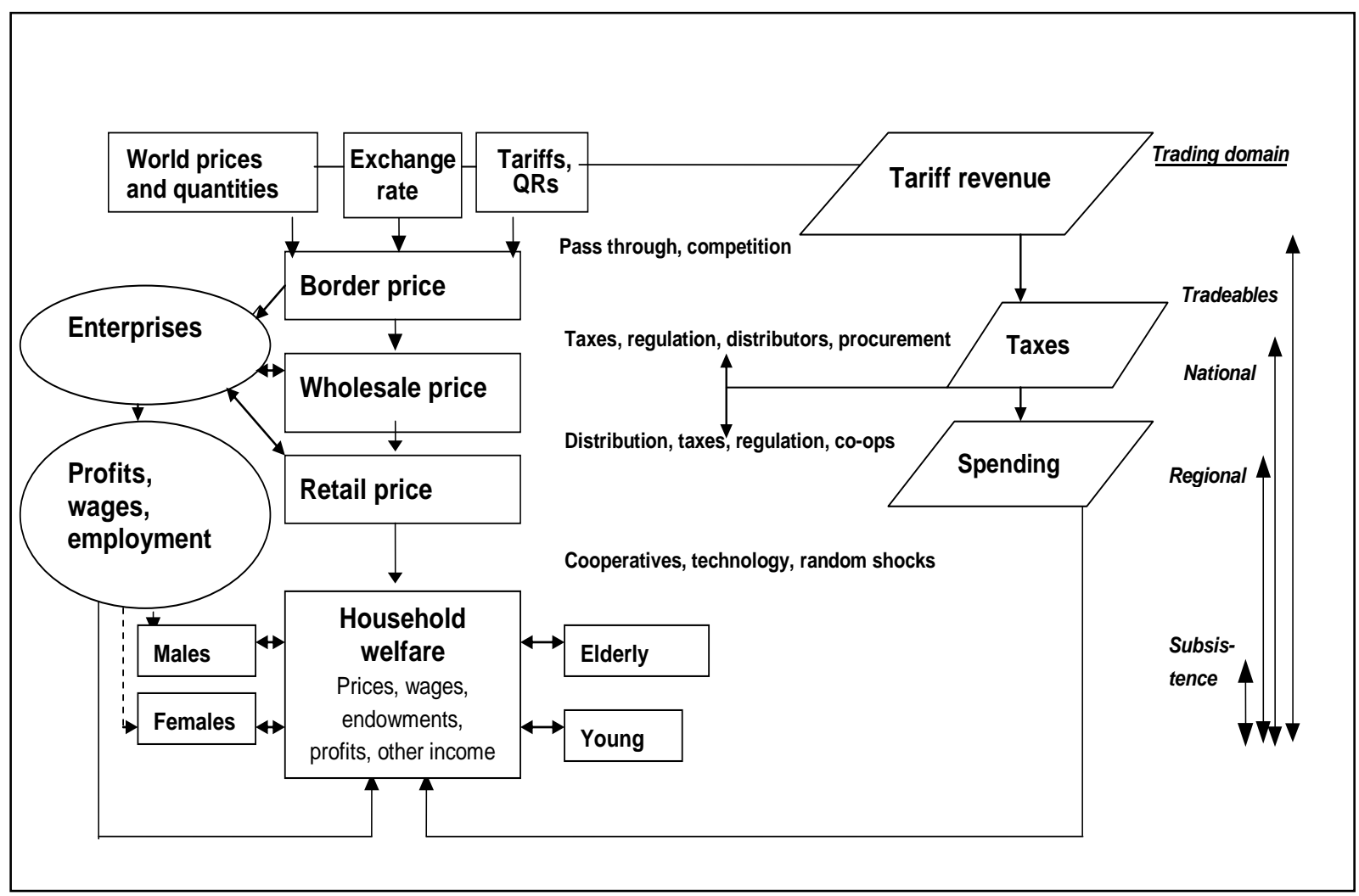

Source: Winters (2002) 
Annex 3

Questionnaire survey for trading firms

Sr. No

\title{
1. Identification of the sample
}

8.1. Name of respondent:

8.2. Address

Telephone: Fax:

\author{
Mobile: \\ E-mail: \\ Website
}

any):

8.3. Name

$\mathrm{Mr} / \mathrm{Ms}$

1.4 Date of survey:

\section{For Office Use Only:}

- Co-operation of respondent: Good/Moderate/Poor

- Reliability of information: High/Moderate/Poor/Very Poor

Reviewed by: Date:

If sent back for verification/correction:

Verification done: Yes/No. If yes, date of verification:

Verified by:

Date:

\subsection{Type of ownership}

\section{Background}

Codes: 1 = Individual proprietorship

2 = Joint family (HUF)

$3=$ Partnership

4 = Private Limited Company

5 = Public Limited Company

$6=$ Government department enterprises

7 = Joint venture between domestic and foreign private companies

8 = Joint venture between domestic private company and government enterprises

9 = Co-operative Society

$10=$ Other (specify)

8.2. How would you describe your business in terms of capital when it was established?

(1) Status of the company

Codes: 1 = Independent

2 = Under holding company

$3=$ Subsidiary of domestic firm

4 = Subsidiary of foreign firm 
$5=$ Other (specify)

If (3) or (4), name of the parent firm

(2) Family based? Yes/No

\subsection{Year of establishment:}

\section{Export/import products}

3.1 Major export/import products. (Please add separate page, if needed.)

\begin{tabular}{|c|c|c|c|c|c|l|}
\hline $\begin{array}{c}\text { Sr. } \\
\text { No. }\end{array}$ & $\begin{array}{c}\text { Name of } \\
\text { export/import } \\
\text { products }\end{array}$ & $\begin{array}{c}\text { HS } \\
\text { codes }\end{array}$ & $\begin{array}{c}\text { Volume } \\
2000-01 \\
\text { (Rs) }\end{array}$ & $\begin{array}{c}\text { Volume } \\
2006-07 \\
\text { (Rs) }\end{array}$ & $\begin{array}{c}\text { Volume } \\
2011-12 \\
\text { (Rs) }\end{array}$ & Destinations/sources \\
\hline & & & & & & \\
\hline & & & & & & \\
\hline & & & & & & \\
\hline & & & & & & \\
\hline
\end{tabular}

3.2 What are the major barriers you face while exporting or importing your products with Bangladesh/Pakistan/both? (Please add separate page, if needed.)

\begin{tabular}{|l|l|l|l|}
\hline $\begin{array}{l}\text { Sr. } \\
\text { No. }\end{array}$ & Type of barrier & Regulating authority(s) & $\begin{array}{c}\text { Scope of } \\
\text { improvement }\end{array}$ \\
\hline & & & \\
\hline & & & \\
\hline & & & \\
\hline & & & \\
\hline
\end{tabular}

3.3 Cost components of export (for every unit of major export) specifically to Bangladesh/Pakistan/both (Rs, or specify unit:

(i) "Production costs

(ii) Transportation costs
(a) India part
(b) Bangladesh/Pakistan part

(iii) Insurance costs
(a) India part
(b) Bangladesh/Pakistan part

(iv) Bank charges
(a) India part
(b) Bangladesh/Pakistan part

(v) Export duty (net of duty drawback)

(vi) Import tariff

(vii) Other charges/costs (specify) 
3.4 What are the checkpoints (customs stations) through which your product is exported/imported to/from Bangladesh/Pakistan? (Please add separate page, if needed.)

3.5 Impediments to exports/imports at the checkpoints

\begin{tabular}{|l|c|c|}
\hline Name of checkpoint & Pakistan & Bangladesh \\
\hline Attari & Wagah & \\
\hline Petrapole & & Benapole \\
\hline & & \\
\hline & & \\
\hline & & \\
\hline
\end{tabular}
(a) Waiting time at the check-posts
Yes/No
If Yes, no. of days for each consignment
(b) Paper work at the customs If Yes, costs and time incurred in clearance: Rs
(c) Different insurance for two countries

Yes/No ${ }^{\text {Yes/No }}$ or time
If Yes, Bangladesh/Pakistan side insurance amount: Rs India side insurance amount: Rs

(d) Different bank charges in two countries Yes/No If Yes, Bangladesh/Pakistan side bank charges: Rs India side bank charges: Rs or $\%$

3.6 Facilities available for imports/exports at the checkpoints (put a $\sqrt{ }$ against each facility)

\begin{tabular}{|c|c|}
\hline Physical impediments & Non-physical impediments \\
\hline $\begin{array}{l}\text { - } \text { Customs } \\
\text { - } \text { Immigration } \\
\text { - } \text { Security } \\
\text { - } \text { Heank } \\
\text { - } \text { Warehouse and parking } \\
\text { - } \text { Congh bridge } \\
\text { - } \text { Container handling yard } \\
\text { equipment } \\
\text { - } \text { Saiting room } \\
\text { - } \text { restaps, hotels and } \\
\text { - } \text { Internet } \\
\text { - } \text { Pelephone } \\
\text { - } \text { Currency exchange } \\
\text { - Any other }\end{array}$ & $\begin{array}{l}\text { - } \text { e-commerce of customs } \\
\text { - } \text { Fast-track cargo clearance } \\
\text { - } \text { Working days (per week) for } \\
\text { customs } \\
\text { - } \text { Transit } \\
\text { - } \text { Dispute settlement } \\
\text { - Standards } \\
\text { - } \text { Any other }\end{array}$ \\
\hline
\end{tabular}

3.7 Barriers faced by exporters/importers at the checkpoints (put a $\sqrt{ }$ against each barrier)

\begin{tabular}{|l|c|c|c|c|c|}
\hline & $\begin{array}{c}\text { Very } \\
\text { low }\end{array}$ & Low & Average & High & $\begin{array}{c}\text { Very } \\
\text { High }\end{array}$ \\
\cline { 2 - 6 } & $\mathbf{1}$ & $\mathbf{2}$ & $\mathbf{3}$ & $\mathbf{4}$ & $\mathbf{5}$ \\
\hline Inadequate infrastructure at checkpoint & & & & & \\
\hline $\begin{array}{l}\text { Poor transportation infrastructure to } \\
\text { access the checkpoint }\end{array}$ & & & & & \\
\hline
\end{tabular}




\begin{tabular}{|l|l|l|l|l|l|}
\hline $\begin{array}{l}\text { Poor telecommunications infrastructure } \\
\text { at checkpoint }\end{array}$ & & & & & \\
\hline Bureaucracy and red-tape at checkpoint & & & & & \\
\hline Corruption and bribery at checkpoint & & & & & \\
\hline $\begin{array}{l}\text { Restrictive government policy and } \\
\text { regulations }\end{array}$ & & & & & \\
\hline High cost of transportation & & & & & \\
\hline Lack of warehouse facilities & & & & & \\
\hline Lack of faster handling equipment & & & & & \\
\hline Lack of trained human resources & & & & & \\
\hline Lengthy paper work at checkpoint & & & & & \\
\hline Others (if any) (specify) & & & & & \\
\hline
\end{tabular}

\section{Employment}

\subsection{Number of employees}

Please fill in the following table for employees (possibly average, if not at the end of the periods)

\begin{tabular}{|l|l|l|l|}
\hline & $\begin{array}{c}\text { At the time of } \\
\text { establishment } \\
\text { (specify } \\
\text { year_fo06-07 }\end{array}$ & $\begin{array}{c}\text { 2011-12 } \\
\text { (Other, } \\
\text { specify }\end{array}$ \\
\hline Total employees & & & \\
\hline Skilled & & & \\
\hline Permanent & & & \\
\hline Unskilled & & & \\
\hline Permanent & & & \\
\hline Casual & & & \\
\hline
\end{tabular}

\section{Service Quality}

5.1 Rate the efficiency of the clearance process (e.g., speed, simplicity and predictability of formalities) by border control agencies including customs (put a $\sqrt{ }$ in the relevant cell)

(a) Speed

\begin{tabular}{|l|l|c|c|c|c|c|}
\hline LCS & Country & $\begin{array}{c}\text { Very } \\
\text { low }\end{array}$ & Low & Average & High & $\begin{array}{c}\text { Very } \\
\text { high }\end{array}$ \\
\hline Attari & India & $\mathbf{1}$ & $\mathbf{2}$ & $\mathbf{3}$ & $\mathbf{4}$ & $\mathbf{5}$ \\
\hline Petrapole & India & & & & & \\
\hline Wagha & Pakistan & & & & & \\
\hline Benapole & Bangladesh & & & & & \\
\hline
\end{tabular}

(b) Simplicity

\begin{tabular}{|l|l|c|c|c|c|c|}
\hline LCS & Country & $\begin{array}{l}\text { Very } \\
\text { low }\end{array}$ & Low & Average & High & $\begin{array}{l}\text { Very } \\
\text { high }\end{array}$ \\
\hline & & 1 & 2 & 3 & 4 & 5 \\
\hline Attari & India & & & & & \\
\hline
\end{tabular}




\begin{tabular}{|l|l|l|l|l|l|l|}
\hline Petrapole & Pakistan & & & & & \\
\hline Wagha & Bangladesh & & & & & \\
\hline Benapole & & & & & & \\
\hline
\end{tabular}

(c) Adherence to rules

\begin{tabular}{|l|l|l|c|c|c|c|}
\hline LCS & Country & $\begin{array}{l}\text { Very } \\
\text { low }\end{array}$ & Low & Average & High & $\begin{array}{l}\text { Very } \\
\text { high }\end{array}$ \\
\hline & & $\mathbf{1}$ & $\mathbf{2}$ & $\mathbf{3}$ & $\mathbf{4}$ & $\mathbf{5}$ \\
\hline Attari & India & & & & & \\
\hline Petrapole & Pakistan & & & & & \\
\hline Wagha & Bangladesh & & & & & \\
\hline Benapole & & & & & & \\
\hline
\end{tabular}

5.2 Evaluate the quality of services in trade and transport related infrastructure (i.e. airports, ports, railways, roads, information technologies, etc) (put a $\sqrt{ }$ in the relevant cell)

(a) Airport

\begin{tabular}{|l|c|c|c|c|c|}
\hline & $\begin{array}{l}\text { Very } \\
\text { low }\end{array}$ & Low & Average & High & $\begin{array}{l}\text { Very } \\
\text { high }\end{array}$ \\
\hline & $\mathbf{1}$ & $\mathbf{2}$ & $\mathbf{3}$ & $\mathbf{4}$ & $\mathbf{5}$ \\
\hline India & & & & & \\
\hline Pakistan & & & & & \\
\hline Bangladesh & & & & & \\
\hline
\end{tabular}

(b) Rail

\begin{tabular}{|l|c|c|c|c|c|}
\hline & $\begin{array}{l}\text { Very } \\
\text { low }\end{array}$ & Low & Average & High & $\begin{array}{l}\text { Very } \\
\text { high }\end{array}$ \\
\hline & $\mathbf{1}$ & $\mathbf{2}$ & $\mathbf{3}$ & $\mathbf{4}$ & $\mathbf{5}$ \\
\hline India & & & & & \\
\hline Pakistan & & & & & \\
\hline Bangladesh & & & & & \\
\hline
\end{tabular}

(c) Road

\begin{tabular}{|l|c|c|c|c|c|}
\hline & $\begin{array}{l}\text { Very } \\
\text { low }\end{array}$ & Low & Average & High & $\begin{array}{l}\text { Very } \\
\text { high }\end{array}$ \\
\hline & $\mathbf{1}$ & $\mathbf{2}$ & $\mathbf{3}$ & $\mathbf{4}$ & $\mathbf{5}$ \\
\hline India & & & & & \\
\hline Pakistan & & & & & \\
\hline Bangladesh & & & & & \\
\hline
\end{tabular}

(d) Ports

\begin{tabular}{|l|c|c|c|c|c|}
\hline & $\begin{array}{l}\text { Very } \\
\text { low }\end{array}$ & Low & Average & High & $\begin{array}{l}\text { Very } \\
\text { high }\end{array}$ \\
\hline & $\mathbf{1}$ & $\mathbf{2}$ & $\mathbf{3}$ & $\mathbf{4}$ & $\mathbf{5}$ \\
\hline India & & & & & \\
\hline Pakistan & & & & & \\
\hline Bangladesh & & & & & \\
\hline
\end{tabular}

(e) Information technology

\begin{tabular}{|l|l|l|l|l|l|}
\hline $\begin{array}{l}\text { Very } \\
\text { low }\end{array}$ & Low & Average & High & $\begin{array}{l}\text { Very } \\
\text { high }\end{array}$ \\
\hline
\end{tabular}




\begin{tabular}{|l|c|c|c|c|c|}
\hline & $\mathbf{1}$ & $\mathbf{2}$ & $\mathbf{3}$ & $\mathbf{4}$ & $\mathbf{5}$ \\
\hline India & & & & & \\
\hline Pakistan & & & & & \\
\hline Bangladesh & & & & & \\
\hline
\end{tabular}

5.3 What is the level of your overall ease of trading with the following countries? (put a $\sqrt{ }$ in the relevant cell)

\begin{tabular}{|l|l|c|c|c|c|}
\hline & $\begin{array}{l}\text { Very } \\
\text { difficult }\end{array}$ & Difficult & Average & Easy & $\begin{array}{l}\text { Very } \\
\text { easy }\end{array}$ \\
\hline & $\mathbf{1}$ & $\mathbf{2}$ & $\mathbf{3}$ & $\mathbf{4}$ & $\mathbf{5}$ \\
\hline India & & & & & \\
\hline Pakistan & & & & & \\
\hline Bangladesh & & & & & \\
\hline
\end{tabular}

5.4. Rate the ability to track and trace your consignment while in transit to the following countries (put a $\sqrt{ }$ in the relevant cell)

\begin{tabular}{|l|l|c|c|c|c|}
\hline & $\begin{array}{l}\text { Very } \\
\text { difficult }\end{array}$ & Difficult & Average & Easy & $\begin{array}{l}\text { Very } \\
\text { easy }\end{array}$ \\
\hline & $\mathbf{1}$ & $\mathbf{2}$ & $\mathbf{3}$ & $\mathbf{4}$ & $\mathbf{5}$ \\
\hline India & & & & & \\
\hline Pakistan & & & & & \\
\hline Bangladesh & & & & & \\
\hline
\end{tabular}

5.5. Evaluate the cargo shipment requirements such as logistics, security and insurance requirements (i.e., screening, advance information etc.) (put a $\sqrt{ }$ in the relevant cell)

\begin{tabular}{|l|l|c|c|c|c|}
\hline & $\begin{array}{l}\text { Very } \\
\text { difficult }\end{array}$ & Difficult & Average & Easy & $\begin{array}{l}\text { Very } \\
\text { easy }\end{array}$ \\
\hline & $\mathbf{1}$ & $\mathbf{2}$ & $\mathbf{3}$ & $\mathbf{4}$ & $\mathbf{5}$ \\
\hline India & & & & & \\
\hline Pakistan & & & & & \\
\hline Bangladesh & & & & & \\
\hline
\end{tabular}

5.6. When arranging shipments to the countries listed below, how often do the consignments reach within the scheduled or expected delivery time? (put a $\sqrt{ }$ in the relevant cell)

\begin{tabular}{|l|c|c|c|c|c|}
\hline & $\begin{array}{c}\text { Hardly } \\
\text { ever }\end{array}$ & Rarely & Sometime & Often & $\begin{array}{c}\text { Nearly } \\
\text { always }\end{array}$ \\
\hline & $\mathbf{1}$ & $\mathbf{2}$ & $\mathbf{3}$ & $\mathbf{4}$ & $\mathbf{5}$ \\
\hline India & & & & & \\
\hline Pakistan & & & & & \\
\hline Bangladesh & & & & & \\
\hline
\end{tabular}

5.7. Based on your experience describe the operational logistic costs in India, compared with other costs of your production (put a $\sqrt{ }$ in the relevant cell)

\begin{tabular}{|l|c|c|c|c|c|}
\hline & Very high & High & Average & Low & Very low \\
\hline & $\mathbf{1}$ & $\mathbf{2}$ & $\mathbf{3}$ & $\mathbf{4}$ & $\mathbf{5}$ \\
\hline Port charges & & & & & \\
\hline Airport charges & & & & & \\
\hline
\end{tabular}




\begin{tabular}{|l|l|l|l|l|l|}
\hline Road transport rates & & & & & \\
\hline Rail transport rates & & & & & \\
\hline $\begin{array}{l}\text { Warehouses/translation } \\
\text { service charges }\end{array}$ & & & & & \\
\hline Agent fees & & & & & \\
\hline Other (specify) & & & & & \\
\hline
\end{tabular}

5.8 Evaluate the quality of trade and transport-related infrastructure (i.e., ports, railways, roads, information technologies etc.) in India (put a $\sqrt{ }$ in the relevant cell)

\begin{tabular}{|l|c|c|c|c|c|}
\hline & Very low & Low & $\begin{array}{c}\text { Averag } \\
\text { e }\end{array}$ & High & $\begin{array}{c}\text { Very } \\
\text { high }\end{array}$ \\
\hline Port & 1 & 2 & 3 & 4 & 5 \\
\hline Airport & & & & & \\
\hline Road & & & & & \\
\hline Rail & & & & & \\
\hline $\begin{array}{l}\text { Warehouses/trans-loading } \\
\text { facilities }\end{array}$ & & & & & \\
\hline $\begin{array}{l}\text { Telecommunications } \\
\text { infrastructure and IT services }\end{array}$ & & & & & \\
\hline
\end{tabular}

5.9 Evaluate the competence and quality of services delivered by the following in India (put a $\sqrt{ }$ in the relevant cell)

\begin{tabular}{|l|c|c|c|c|c|}
\hline & Very low & Low & $\begin{array}{l}\text { Averag } \\
\text { e }\end{array}$ & High & Very high \\
\hline Road transport services provider & $\mathbf{1}$ & $\mathbf{2}$ & $\mathbf{3}$ & $\mathbf{4}$ & $\mathbf{5}$ \\
\hline Rail transport services provider & & & & & \\
\hline Air transport services provider & & & & & \\
\hline Maritime transport services provider & & & & & \\
\hline $\begin{array}{l}\text { Warehouses/trans-loading and } \\
\text { distribution operators }\end{array}$ & & & & & \\
\hline Freight forwarding & & & & & \\
\hline Customs agents related & & & & & \\
\hline Quality/standards inspection agencies & & & & & \\
\hline $\begin{array}{l}\text { Health/SPS (Sanitary Phytosanitary) } \\
\text { agencies }\end{array}$ & & & & & \\
\hline $\begin{array}{l}\text { Trade and transport radiations } \\
\text { associans }\end{array}$ & & & & & \\
\hline Consignees or shippers & & & & \\
\hline
\end{tabular}

5.10 How many documents do you submit to border-related government agencies involved in the clearance process for export and imports including customs?

\begin{tabular}{|l|l|}
\hline & $\begin{array}{l}\text { Number } \\
\text { documents }\end{array}$ \\
\hline Pakistan (Attari) & \\
\hline $\begin{array}{l}\text { Bangladesh } \\
\text { (Petrapole) }\end{array}$ \\
\hline
\end{tabular}


5.11 The average time taken for imports and exports after declaration and notification of clearance

\begin{tabular}{|l|c|c|}
\hline & Pakistan & Bangladesh \\
\hline Without physical inspection & & \\
\hline With physical inspection & & \\
\hline
\end{tabular}

5.12 Evaluate the following statements regarding customs at check post (put a $\sqrt{ }$ in the relevant cell)

\begin{tabular}{|l|l|l|l|l|}
\hline & Yes & No & N/A & $\begin{array}{l}\text { Do not } \\
\text { Know }\end{array}$ \\
\hline Can the customs declaration be submitted online? & & & & \\
\hline $\begin{array}{l}\text { Does customs allow for pre-arrival clearance of } \\
\text { merchandise/shipments for imports? }\end{array}$ & & & \\
\hline $\begin{array}{l}\text { Does the customs code require importers to use a } \\
\text { licensed custom broker to clear goods? }\end{array}$ & & & \\
\hline $\begin{array}{l}\text { Does customs use post-clearance audit for } \\
\text { imports? }\end{array}$ & & & \\
\hline $\begin{array}{l}\text { Are you and your customers able to choose the } \\
\text { location of the final clearance of the goods for } \\
\text { imports? }\end{array}$ & & & & \\
\hline $\begin{array}{l}\text { Can goods be released pending final clearance } \\
\text { against an accepted guarantee? }\end{array}$ & & & \\
\hline $\begin{array}{l}\text { Are you and your peers invited for dialogue by } \\
\text { customs through a formal process (periodic } \\
\text { meetings, consultative forums, committees etc.)? }\end{array}$ & & & & \\
\hline $\begin{array}{l}\text { In the case of a dispute with customs or other } \\
\text { border agencies, is a review/appeal procedure } \\
\text { available? }\end{array}$ & & & & \\
\hline $\begin{array}{l}\text { Do you receive advance notification of binding } \\
\text { changes with regard to tariff classification, } \\
\text { valuation or rules of origin? }\end{array}$ & & & & \\
\hline
\end{tabular}

\section{Perception of poverty}

6.1 Do you think poverty has gone down during the past five years for you? Yes/No.

If yes, do you think cross-border trade with Pakistan/Bangladesh is one of the major factors responsible for this? Yes/No

Perception of local people/exporters/importers about poverty-alleviating role of international trade

1. Name of the respondent:

Sr. No

2. Address:

Telephone:

Fax:

Mobile:

E-mail:

Website (if any):

3. Date of survey: 
4. Type of ownership:

Codes: 1 = Exporter $2=$ Importer $3=$ Individual 4 = Other (specify):

5. How are you related to this trade?

- Transporter

- Foreign exchange dealer

- Helper in loading/unloading of cargo

- Local trade agent

- Repair mechanic

- Dhaba worker

- Dhaba employer

- Hotel operator

- Any other (please mention)

6. In which year did you join in this service?

7. How much do you earn from this trade activity?

\begin{tabular}{|l|l|l|l|}
\hline & $\begin{array}{c}\text { First year } \\
(2000-01)\end{array}$ & $2006-07$ & $2011-12$ \\
\hline Daily (in Rs) & & & \\
\hline Weekly (in Rs) & & & \\
\hline Monthly (in Rs) & & & \\
\hline
\end{tabular}

8. Do you want trade to rise? Yes/No

If Yes, what are the impediments to an increase in trade activity?

(a) Lack of infrastructure (on a scale of 1 to 5)

\begin{tabular}{|l|c|c|c|c|c|}
\hline & $\begin{array}{l}\text { Very } \\
\text { bad }\end{array}$ & Bad & Average & Good & $\begin{array}{l}\text { Very } \\
\text { good }\end{array}$ \\
\hline Customs & $\mathbf{1}$ & $\mathbf{2}$ & $\mathbf{3}$ & $\mathbf{4}$ & $\mathbf{5}$ \\
\hline $\begin{array}{l}\text { Transport } \\
\text { infrastructure }\end{array}$ & & & & & \\
\hline Banks and & & & & & \\
\hline $\begin{array}{l}\text { Hotels } \\
\text { restaurants }\end{array}$ & & & & & \\
\hline $\begin{array}{l}\text { Servicing } \\
\text { facilities }\end{array}$ & & & & & \\
\hline $\begin{array}{l}\text { Communications } \\
\text { facilities }\end{array}$ & & & & & \\
\hline
\end{tabular}

(b) Poor governance (on a scale of 1 to 5)

\begin{tabular}{|l|c|c|c|c|c|}
\hline & $\begin{array}{c}\text { Very } \\
\text { bad }\end{array}$ & Bad & Average & Good & $\begin{array}{c}\text { Very } \\
\text { good }\end{array}$ \\
\hline High security & $\mathbf{1}$ & $\mathbf{2}$ & $\mathbf{3}$ & $\mathbf{4}$ & $\mathbf{5}$ \\
\hline Local mafia of & & & & & \\
\hline $\begin{array}{l}\text { Lack in } \\
\text { transparency } \\
\text { information }\end{array}$ & & & & & \\
\hline $\begin{array}{l}\text { Minority/religious } \\
\text { tensions }\end{array}$ & & & & & \\
\hline Cheating & & & & & \\
\hline
\end{tabular}




\begin{tabular}{|lr|l|l|l|l|l|}
\hline $\begin{array}{l}\text { Strikes and } \\
\text { closedown } \\
\text { operation }\end{array}$ & & & & & \\
\hline
\end{tabular}

If no, specify the reasons:

9. Exporters/importers

(i) Do you think better trade will reduce poverty locally? Yes or No. If Yes, rank the following on a scale of 1 to 5 , where 5 is agree and 1 is disagree.

- More jobs

- Higher income

- Better skills

- Better knowledge about income opportunities

- Expansion of local production

(ii) Do you think improvement of trade facilitation at borders will reduce poverty locally? Yes or No. If Yes, rank the following on a scale 1 to 5 where 5 is agree and 1 is disagree.

- More jobs

- Higher income

- Better skills

- Better knowledge about income opportunities

- Expansion of local production

(iii) Do you think upgrading skills has created improvements? Yes or No. If Yes, rank the following on a scale of 1 to 5 where 5 is agree and 1 is disagree.

- Faster cargo handling

- Well informed/quality decision at work

- More professionalism at work

- Honesty and integrity at work

- Better communications

10. Do you think poverty has gone down during the past five years for you? Yes/No. Yes/No

If Yes, do you think cross-border trade is one of the major responsible factors for this? 


\section{References}

Anderson, J. E. and E. van Wincoop (2004). "Trade costs", Journal of Economic Literature, vol. 42, No. 3; pp. 691-751.

Arvis, J. F., Y. Duval, B. Shepherd and C. Utoktham (2012). "Trade costs in the developing world: 1995-2010", ARTNeT Working Paper No. 121, ESCAP, Bangkok. Available online at www.artnetontrade.org.

Bandara, J. S., P. Athukorala and S. Kelegama (eds.) (2011). Trade Liberalisation and Poverty in South Asia, Routledge, Oxford, United Kingdom.

Barro, R. J. (1990). "Government spending in a simple model of endogenous growth", Journal of Political Economy, Vol. 98, No. 5, pp. S102- S125.

Barro, R. J. (1991). "Economic growth in a cross-section of countries", Quarterly Journal of Economics, Vol. 106, pp. 407-443.

Brooks, D. H. and D. Hummels (eds.) (2009). Infrastructure's Role in Reducing Asia's Trade Costs: Building for Trade. Edward Elgar, Cheltenham, United Kingdom and Massachusetts, United States, and Asian Development Bank Institute, Tokyo.

Brooks, D. H. and S. F. Stone (eds.) (2010). Trade Facilitation and Regional Cooperation in Asia. Edward Elgar, Cheltenham, United Kingdom, and Asian Development Bank Institute, Tokyo.

Campano, F. and D. Salvatore. (2007). "Economic development and income distribution", Journal of Policy Modeling, Vol. 29, pp. 553-566.

CIE (2012) "Economic benefits of trade facilitation in the Greater Mekong Subregion”, Centre for International Economics, Canberra and Sydney.

De, P. S. Raihan, and E. Ghani (2013) "What does MFN trade mean for India and Pakistan? can MFN be a Panacea?", Policy Research Working Paper Series 6483, World Bank, Washington, D.C.

De, P. (2009a). "Empirical estimates of transportation costs: Options for enhancing Asia's trade", in D. H. Brooks and D. Hummels (eds.), Infrastructure's Role in Lowering Asia's Trade Costs: Building for Trade. Edward Elgar, Cheltenham, United Kingdom.

— (2009b). "Inclusive growth and trade facilitation: Insights from South Asia", ARTNeT Policy Brief No. 16. ESCAP, Bangkok.

Deardorff, A. V. (2001). "International provision of trade services, trade, and fragmentation", Review of International Economics, vol. 9, No. 2; pp. 233-248. 
Diopa, N., P. Brentona and Y. Asarkayab (2005) "Trade costs, export development and poverty in Rwanda", Working Paper \# WPS3784, The World Bank, Washington, D.C.

Edwards, S. (1997). "Trade policy, growth, and income distribution", American Economic Review, vol. 87, No. 2; pp. 205-210.

Ferreira Francisco H.G., Phillippe G. Leite and Matthew Wai-Poi (2007) "Trade liberalization, employment flows and wage inequality in Brazil", Policy Research Working Paper 4108, The World Bank, Washington, D.C.

Edmonds, C., and M. Fujimura. 2008. "Road Infrastructure and Regional Economic Integration: Evidence from the Mekong", in D. Brooks and J. Menon (eds.) Infrastructure and Trade in Asia, Cheltenham: Edward Elgar.

Gourdon, J., N. Maystre, and J de Melo. (2008). "Openness, inequality and poverty: endowments matter", The Journal of International Trade and Economic Development, Vol. 17, No. 3, pp. 343-378

Harrison, A., J. McLaren, and M. S. McMillan (2010). "Recent Findings on Trade and Inequality", Working Paper 16425, National Bureau of Economic Research (NBER), Cambridge

Isik-Dikmelik, Aylin (2006) "Trade Reforms and Welfare: An Ex-Post Decomposition of Income in Vietnam", Policy Research Working Paper 4049, The World Bank, Washington, D.C.

Limao, N. and A. J. Venables (2001). "Infrastructure, geographical disadvantage, transport costs and trade", World Bank Economic Review, vol. 15, pp. 451-479. Washington, D.C.

Menon, J (2006). “Does Road Improvement Reduce Poverty? A General Equilibrium Analysis for Lao PRD”, IDB Publications 44320, Inter-American Development Bank (IDB), New York.

Menon J. and P. Warr (2006) "Does Road Improvement Reduce Poverty? A General Equilibrium Analysis for Lao PDR", Asian Development Bank Institute (ADBI), Tokyo

Meschi, E. and M. Vivarelli (2009). "Trade and income inequality in developing countries", World Development, vol. 37, No. 2; pp. 287-302.

Overseas Development Institute (2003) "Income Distribution Impact of Trade Facilitation in Developing Countries", Background Paper Prepared for the International Forum in Trade Facilitation, Geneva, 14/15th May, 2003.

Organisation for Economic Co-operation and Development (2003). "Quantitative assessment of the benefits of trade facilitation", TD/TC/WP(2003)31/FINAL. Paris. 
Raychaudhuri, A. and P. De. (2010). :Trade, Infrastructure and Income Inequality in Selected Asian Countries: An Empirical Analysis", ARTNeT Working Paper 82, ESCAP, Bangkok

Raychaudhuri, A. and P. De. (2012). International Trade in Services in India: Implications for Growth and Inequality in a Globalizing World, Oxford University Press, New Delhi. Raychaudhuri, A and P. De (2013) "Economic Corridors, Trade Costs, and Regional Production Networks in South Asia", in Prabir De and Kavita lyengar (eds.) Developing Economic Corridors in South Asia, Asian Development Bank (ADB), Manila.

Sahai, P. S., and V. Laxmi (2013) "Transit and trade facilitation across South Asian corridors: India-Pakistan land connectivity", in P. De and K. lyengar (eds.), Developing Economic Corridors in South Asia. Asian Development Bank, Manila.

Singh, Tarlok (2010) "Does International Trade Cause Economic Growth? A Survey", The World Economy, Vol. 33, Issue 11, pp. 1517-1564

Slaughter, M. J. (1997) "Per capita income convergence and the role of international trade", American Economic Review, Vol. 87, No. 2, pp. 194-199.

Stone, S., A. Strutt, and T. Hertel,(2010) "Assessing Socioeconomic Impacts of Transport Infrastructure Projects in the Greater Mekong Subregion," ADBI Working Papers 234, Asian Development Bank Institute (ADBI), Tokyo

Srivastava, P. and U. Kumar (eds.) (2012). Trade and Trade Facilitation in the Greater Mekong Subregion. Asian Development Bank, Manila. United Nations (2003) Income Distribution Impact of Trade Facilitation in Developing Countries, Background Paper for the $2^{\text {nd }}$ International Forum on Trade Facilitation, organized by the Committee for Trade, Industry and Enterprise Development (CTIED) and the United Nations Centre for Trade Facilitation and Electronic Business (UN/CEFACT) on 14 and 15 May 2003 in Geneva, Economic Commission of Europe, Geneva

Warr, P (2007) "How do infrastructure projects benefit the poor?", in Clem Tisdell (ed.), Poverty, Poverty Alleviation and Social Disadvantage: Analysis, Case Studies and Policies, Serials Publications, New Delhi, India, pp. 88-103.

Warr, Peter, J. Menon, and A. A. Yusuf (2009). "Regional Economic Impacts of Cross-Border Infrastructure: A General Equilibrium Application to Thailand and Lao PDR", Working Papers on Regional Economic Integration 35, Asian Development Bank, Manila. 
Wiemer, C. (2009). "Economic Corridors for the Greater Mekong Subregion", EAl Background Brief No. 479, East Asian Institute, National University Singapore, Singapore.

Winters, A. L., N. McCulloch and A. McKay (2004). "Trade Liberalization and poverty: The evidence so far", Journal of Economic Literature, vol. 42, No. 1; pp. 72-115.

Winters, Alan, L (2000a) “Trade Liberalisation and Poverty”, PRUS Working Paper 7, Poverty Research Unit at Sussex, University of Sussex, Sussex

Winters, Alan, L. (2000b) “Trade, Trade Policy and Poverty: What are the Links?", CEPR Discussion Paper No. 2382, London.

Winters, A. L. (2002). "Trade liberalisation and poverty: What are the links?" World Economy, vol. 25, No. 9; pp. 1339-1367. 


\section{ARTNeT Working Paper Series}

is available at www.artnetontrade.org

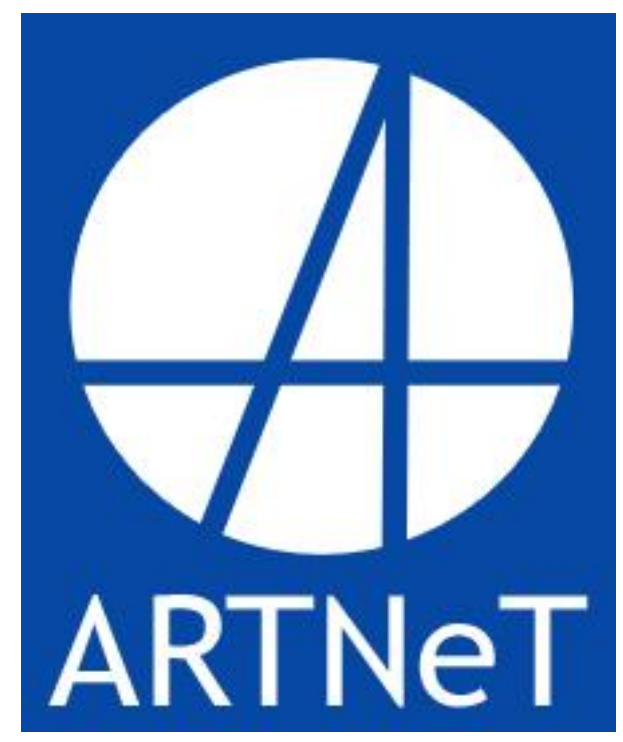

\begin{tabular}{|r|}
\hline ARTNeT Secretariat \\
United Nations \\
Economic and Social Commission \\
for Asia and the Pacific \\
Trade and Investment Division \\
United Nations Building \\
Rajadamnern Nok Avenue \\
Bangkok 10200, Thailand \\
Tel: $+66(0) 2-288-2251$ \\
Fax: $+66(0) 2-288-1027$ \\
Email: artnetontrade@un.org \\
Website: www.artnetontrade.org \\
\hline
\end{tabular}

